\title{
Self-selection of entrepreneurial firms in thin venture capital markets: theory and empirical evidence
}

\author{
Fabio Bertoni \\ EmLyon Business School \\ Diego D'Adda \\ Università Politecnica delle Marche - Dipartimento di Ingegneria dell'Informazione \\ Luca Grilli^ \\ Politecnico di Milano, Department of Management, Economics and Industrial Engineering
}

We all acknowledge support from the Venture Fun project promoted by the EU PRIME Network of Excellence and the VICO project funded under FP7 (SSH-2007-1.2.3-G.A. 217485).

• Corresponding author: Luca Grilli (luca.grilli@polimi.it), tel.: +39-02-2399-3955, fax: +39-02-

2399-2710, Politecnico di Milano - Department of Management, Economics and Industrial Engineering, Via Lambruschini 4/b, 20156 Milan (Italy).

\section{RESEARCH SUMMARY}

\begin{abstract}
We develop a two-step selection model between entrepreneurial ventures and venture capital (VC) investors in a thin VC market. The model predicts that in a thin VC market, the availability of $\mathrm{VC}$ reduces the propensity of firms to self-select into the market for VC (demand-side selection) but not the probability that firms entering the market for $\mathrm{VC}$ will receive financing (supply-side selection). We test these predictions using survey-based data on 190 new technology-based firms in Italy during the late 1990 s and early 2000s. The empirical evidence supports the predictions of the model.
\end{abstract}

\section{MANAGERIAL SUMMARY}

Venture capital (VC) is an important ingredient of an environment that is conducive to the birth and the growth of entrepreneurial ventures; but VC markets are often highly local and thin in terms of participants. We show that the scarcity of VC supply may cause a drop in the demand for VC, because entrepreneurs, anticipating that competition for VC money will be tough, will not seek VC in the first place. The more a market is thin, the more the demand-side selection is likely to become more important than the supply-side selection of VC investors. Demand-side selection may involve a significant number of otherwise good targets for VC investment, which will not be in the radar of VC investors. In turn, this may deter new VC investors from entering the local market, thus creating a vicious cycle that raises concerns for both policy makers and $\mathrm{VC}$ general partners.

This article has been accepted for publication and undergone full peer review but has not been through the copyediting, typesetting, pagination and proofreading process, which may lead to differences between this version and the Version of Record. Please cite this article as doi: $10.1111 /$ sej.1280 
Keywords: High-tech Entrepreneurship, Entrepreneurial Firms, Venture Capital, Selection, Market Thinness

JEL codes: L26, G24, M13

\section{INTRODUCTION}

Venture capital (VC) is commonly considered by academics, practitioners, and policymakers to be the most suitable mode of financing for high-tech entrepreneurial ventures (or New Technology-Based Firms, NTBFs), which are acutely exposed to capital market imperfections. Banks usually do not possess the competencies required to evaluate and to monitor NTBFs (Himmelberg and Petersen 1994, Carpenter and Petersen 2002). While, in principle, adverse selection and moral hazard problems could be alleviated by collateralized loans (Berger and Udell 1998), these instruments are extremely inefficient for NTBFs, the value of which is mostly in intangible assets that can hardly be pledged as collateral. Difficult access to external financing may limit the growth and even threaten the survival of NTBFs. This is a key policy issue, as NTBFs are deemed to play a crucial role in the static and dynamic efficiency of economic systems and, ultimately, are an important engine for the growth of modern economies (Carlsson et al. 2009, Kane 2010).

However, entrepreneurs located in different countries or in different regions of the same country face very different conditions in their ease of access to VC. This is due to the concurrence of three factors. Firstly, VC investors are not evenly distributed geographically but are concentrated in some regions (Sorenson and Stuart 2001, Cumming and Dai 2010, Chen et al. 2010). For instance, US venture capitalists are mainly concentrated in three specific geographical areas (California, Massachusetts, and New York). Secondly, VC investors tend to invest locally because of their handson investment approach, which requires spatial proximity. In fact, closeness improves coaching and monitoring by allowing more frequent contact (Lerner 2009, Bernstein et al. 2016). As a result, evidence from the US (Sorenson and Stuart 2001, Gompers and Lerner 2004, Chen et al. 2010) and 
Europe (e.g., Lutz et al. 2013, Bertoni et al. 2015) shows that most investee firms are located close to their VC investors. Moreover, a lack of local investors is not easily compensated by outside VC investors because the latter typically need the screening and monitoring capabilities of local partners when they invest outside of their local environment (Mäkelä and Maula, 2008, Devigne et al. 2013). Thirdly, entrepreneurs have a strong tendency to locate their businesses in their home regions (Michelacci and Silva 2007, Dahl and Sorenson 2009, 2012), which are not necessarily regions in which VC is particularly abundant. In summary, both entrepreneurs (who are reluctant to establish their companies outside of their home regions) and VC investors (who are reluctant to invest outside of the regions where they operate) are characterized by location biases. The result is that entrepreneurs in different countries, and in different regions within the same country, may face substantially different local VC markets.

These location biases are likely to be influenced by the thinness of the VC market. Following Gans and Stern (2010), we consider the VC market to be thin when it is characterized by a limited number of buyers (i.e., VC investors) and sellers (i.e., firms actively seeking VC). Generally speaking, a thin market is less functional than a thick market (e.g., Roth 2007, Gans and Stern 2010). Specifically, we expect local biases to be even more pronounced in thin markets than in thick markets. In a thin $\mathrm{VC}$ market, the transmission of information about possible investment prospects is limited (Sorenson and Stuart 2001), and because this information is often geographically bounded (Ragozzino and Reuer 2011), market thinness will result in a stronger location bias of VC investors. As will be shown later, market thinness in a country can also reinforce the home bias of entrepreneurs by discouraging movements from regions where $\mathrm{VC}$ is below-average and towards regions where $\mathrm{VC}$ is above average (yet still scarce).

In this paper, we focus on the demand-side and supply-side elements of the two-step selection process between entrepreneurial ventures and VC investors in thin $\mathrm{VC}$ markets. In these markets, which represent the rule rather than the exception at a global level (see, e.g., European Parliament 2012, EY 2014), a non-negligible fraction of entrepreneurial ventures often do not actively seek VC (e.g., Bank of England 2001, Colombo and Grilli 2010, Bertoni et al. 2016; see Cressy and Olofsson This article is protected by copyright. All rights reserved. 
1997 for an earlier discussion of demand-side constraints). In this paper, we argue that the scarcity of local VC investors, coupled with the existence of entry costs, discourages firms from seeking VC. An entrepreneur establishing her company in an area where VC is scarce will anticipate that competition for $\mathrm{VC}$ will be tough and will be more likely to self-select out of the market for VC (demand-side selection). We will show that, in thin VC markets, this demand-side selection is likely to be more important than the supply-side selection that VC investors make among firms that actively seek VC. Demand-side selection may involve a significant number of otherwise good targets for VC investment and also deter new VC investors from entering the local market, raising concerns for both policy makers and VC general partners.

Although there is a vast literature about the selection process from the perspective of VC (see, e.g., Tyebjee and Bruno 1984, Hall and Hofer 1993, Zacharakis and Meyer 1998, 2000; Zacharakis and Shepherd 2001, Baum and Silverman 2004, Petty and Gruber 2011), only a handful of studies have analyzed the decisions that entrepreneurial ventures make about whether to enter the market for VC. To some extent, the investor is often viewed by this literature as the leading party in the investment process, while the entrepreneur is often perceived as a passive target. Conversely, a more recent stream of literature has applied a two-sided market perspective to the analysis of dyadic relationships (for a review, see Chiappori and Salanié 2016). One prominent example is the paper by Sørensen (2007), who develops a matching model between VC investors and entrepreneurs in the most highly developed VC markets in the US: Silicon Valley and the Boston area. His analysis documents a strongly positive assortative matching in that specific context, i.e., more experienced VC investors are more likely to invest in the best entrepreneurial ventures. This type of study mainly focuses on the interesting issue of 'who collaborates with whom' (Mindruta et al. 2016, p. 207). However, the questions of which firms choose to enter the market and whether and to what extent some market characteristics (e.g., supply thinness) may lead firms to self-select are left in the background of the analysis. Relatedly, Sørensen (2007, pp. 2756-2757) suggests that a "broader range of concerns than just matching" should be explored in the future search for possible causes of VC market inefficiencies. It is worth noting that our research question can thus be considered an This article is protected by copyright. All rights reserved. 
antecedent to this literature: if the thinness of venture capital markets influences an entrepreneurial venture's decision to enter (or not enter) the market for $\mathrm{VC}$, this may - clearly - have a direct impact on the spectrum of available matching possibilities within the market.

Demand-side selection has been analyzed and documented in the entrepreneurial finance literature mostly in the context of bank debt (e.g., Kon and Storey 2003). Among the few exceptions that emphasize the active role of entrepreneurial ventures in investment decisions, a handful of qualitative and argumentative studies (e.g., Mason and Harrison 2001, Carpentier and Suret 2006) suggest that the search for VC investments by entrepreneurial ventures may bear high opportunity costs, especially in less developed markets. These opportunity costs may result in demand-side selection, even in the presence of non-allocated funds due to the shortage of available investing opportunities.

To study this phenomenon, we build a two-step selection model between VC investors and NTBFs, which explicitly takes into account the sequential nature of the selection process. In the first step (demand-side selection), NTBFs self-select and decide whether to actively search VC (i.e., to be in the market for VC). In the second step (supply-side selection), venture capitalists make their investment decisions among the firms that - in the first step of the selection process - decided to enter the competition. The objective of our theoretical paper is to formally illustrate how the thinness of the local VC supply exacerbates demand-side selection, leaving supply-side selection virtually unaffected.

The predictions of the theoretical model are tested on a hand-collected dataset composed of 190 Italian NTBFs operating in high-tech manufacturing and services sectors in the early 2000s. We analyze both the determinants of the decisions by NTBFs to enter the market for VC and the selective pressure that investors exert on the firms that effectively entered the market for $\mathrm{VC}$. We set our empirical analysis in Italy, a rather adverse environment for VC during the observed time frame (Groh et al. 2010), making it an ideal test-bed for our study. We find strong evidence of demand-side selection: the probability of seeking VC significantly decreases if an NTBF is located in a region with low VC availability. Moreover, as predicted by our model, we show that supply side selection is not affected by the availability of VC: once we control for demand-side selection, the local availability of VC does not influence the likelihood that a company receives VC. 


\section{THEORY}

In this Section, we develop a formal model describing the endogenous sequential selection process between investors and entrepreneurial ventures in a thin VC market. Following Eckhardt et al. (2006) and Bertoni et al. (2016), we model selection in a thin VC market as a two-step process. First, demand-side selection occurs when an entrepreneurial venture decides if it wants to enter the market for VC (i.e., actively seek VC). Then, supply-side selection takes place as the VC investor selects investment targets among companies in the $\mathrm{VC}$ market.

The important difference between our theoretical setting and that used by Eckhardt et al. (2006) is that we focus on the endogenous link between the first and second steps of the selection process, whereas Eckhardt et al. (2006) focus mostly on the different factors driving each of the two steps. The main difference between our study and the analysis by Bertoni et al. (2016) is that we are not interested in the characteristics of entrepreneurial ventures that affect their decisions to enter the market; rather, we are interested in how the thinness of the market affects these decisions.

Formally, we will study the competition among $N$ entrepreneurs located in a specific geographical region and competing for one $\mathrm{VC}$ investment. While each of the $N$ entrepreneurs could potentially benefit from receiving $\mathrm{VC}$, only $n<N$ entrepreneurs will actually actively seek $\mathrm{VC}$, and only one of these $n$ entrepreneurs will eventually obtain it. This setup is relatively simple (e.g., we consider neither assortative matching between entrepreneurs and different types of VC investors nor collusion or syndication among them) and allows us to obtain closed-form solutions with clear economic interpretability. However, despite its simplicity, the model allows us to illustrate how VC markets work when VC is in extremely scarce supply.

We can think of $N$ as a measure of the thinness of the market for VC: entrepreneurs in our model only have one chance to be selected by VC, and they know that they potentially have to compete with other $N-1$ entrepreneurs. Put differently, the greater $N$ is, the lower the unconditional probability $(1 / N)$ that any of the entrepreneurs will eventually obtain VC money. We can think of $n$ as the VC deal flow, which is the number of options from which a VC can select its investment (Hochberg et al. 2007). Because $N$ - $n$ firms self-select out of the market for VC, investors will not be able to consider This article is protected by copyright. All rights reserved. 
them as investment opportunities. Intuitively, our objective is to show how the tendency of firms to be in the market for $\mathrm{VC}$ (i.e., the ratio $n / N)$ varies with market thinness $(N)$ and how demand-side selection (i.e., the decision of the entrepreneur to be in the market for VC or not) and supply-side selection both vary as the thinness increases.

The endogeneity of the two-step process is intuitive: if an entrepreneur deems it unlikely that her company would ever receive VC, she will not seek it in the first place. This self-selection out occurs because seeking VC is costly for the entrepreneur. This cost of entering the market for VC is not negligible in the real world and reflects the fact that entrepreneurs have to contact VC investors, write a solid business plan, present their project, and participate in the due diligence process. While it is hard to quantify these entry costs, a study of approximately 200 startups showed that getting VC required, on average, contacting 56 investors, meeting with 40 of them, and spending 12.5 weeks to close the deal (Eisenmann 2015). Especially for entrepreneurial ventures, these costs are likely to be extremely relevant, given the absence of slack resources and the high opportunity costs of entrepreneurs' time. ${ }^{1}$

We will demonstrate that entry costs are exacerbated by the thinness of the $\mathrm{VC}$ market and that the fraction of entrepreneurs that actively seek VC (i.e., $n / N$ ) declines with market thinness (i.e., with $N)$. The two-step selection process is such that when the VC market is very thin, an increase in the number $(N)$ of potential competitors for VC only marginally affects the expected number of firms actively seeking $\mathrm{VC}(E[n])$ by leading to a decrease in the ratio $n / N$. Put differently, we will show that in thin VC markets, demand-side selection outweighs supply-side selection.

\section{Supply-side and demand-side selection in thin VC markets}

We develop a simple theoretical model in which the two-step selection process is modeled as an auction with private values and endogenous entry in a local market for a monopolistic VC. The

\footnotetext{
${ }^{1}$ Although we do not have a pure monetary estimate of the entry costs for NTBFs, we do have some evidence that these costs are relevant and strongly affect entrepreneurial ventures. In a questionnaire administered to the firms in our sample, we explicitly asked about the main motivation for not actively seeking VC. Out of 47 respondents that did not actively seek VC but agreed that VC would have been useful, $23(49 \%)$ indicated entry costs as the primary reason. The remaining firms declared that they did not want to lose control of their firm (22 firms, 47\%) or that they did not want an increase in bureaucratic burdens ( 2 firms, $4 \%$ ).
}

This article is protected by copyright. All rights reserved. 
timeline of the model is depicted in Figure 1. At time $t=0, N$ entrepreneurial ventures (i.e., NTBFs) potentially competing for a $\mathrm{VC}$ investment are created. At time $t=1$, the entrepreneurs who want to actively seek VC will incur an entry cost $s$. The entry cost is borne by the entrepreneur and is sunk, i.e., it is not reimbursed if the attempt to obtain $\mathrm{VC}$ is unsuccessful. At time $t=2$, the $\mathrm{VC}$ investment is made in one of the $n \leq N$ companies that, at $t=1$, decided to enter the market for VC.

[Figure 1 about here]

The overall value created by VC financing in a generic company $j$ is given by $I_{j}$. We may think of $I_{j}$ as the overall synergy created by $\mathrm{VC}$ value-enhancing activities. The value created by the $\mathrm{VC}$ investment is split between the investor and the entrepreneur depending on their relative levels of bargaining power, which, in turn, depend on the competition for $\mathrm{VC}$. The number $(N)$ of entrepreneurs potentially competing for $\mathrm{VC}$, the entry cost $(s)$ incurred to actively seek $\mathrm{VC}$, and the probability distribution of $I$ are all public information. However, $I_{j}$ is private information for entrepreneur $j$ and is not known by other entrepreneurs or by the VC investor. We assume, without loss of generality, that ventures are ranked in decreasing order of $I_{j}$ so that $I_{j} \leq I_{j+1}$.

Let $g(i)$ be the probability density function of $I_{j}$ and $G(i)$ be its cumulative distribution. For the sake of simplicity, we assume that $G(i)$ is a smooth and monotonically increasing function such that $G(0)=0$ and $G(1)=1$. In other words, we assume that VC is not expected, ex-ante, to destroy value in any of the $N$ entrepreneurial ventures and that there is a maximum expected value creation level, which we normalize to 1 . We also assume, for the sake of tractability, that all players in the game are risk-neutral and that there is no collusion among entrepreneurs.

Bertoni et al. (2016) show that in the presence of entry costs $s$ and $N$ potential competitors, an entrepreneur characterized by a potential VC impact $I_{j}$ will decide to enter the market for VC only if $I_{j} \geq \widetilde{I}$, where:

$$
\widetilde{I}=s \cdot G(\widetilde{I})^{1-N}
$$


Equation (1) highlights that although all $N$ entrepreneurs could potentially benefit from obtaining $\mathrm{VC}$, the existence of a non-refundable entry cost will keep some of them out of the market for VC. Using the implicit function theorem on Equation (1), we can show that the threshold $\widetilde{I}$ increases monotonically with the number of potential competitors $N$. Specifically, elementary calculus leads to the following partial derivative:

$$
\frac{\partial \widetilde{I}}{\partial N}=\frac{\widetilde{I} \cdot \ln \left(G(\widetilde{I})^{-1}\right)}{1+(N-1) \cdot \widetilde{I} \cdot g(\widetilde{I}) \cdot G(\widetilde{I})^{-1}} \geq 0
$$

Put differently, Equation (2) shows that demand-side selection becomes more and more severe the thinner the VC market is: when many potential competitors could decide to enter the market for VC, each of them will be more reluctant to incur the costs of entering the market for VC. This translates into our first empirically testable hypothesis:

Hypothesis 1. The thinness of VC in a geographical area increases the probability that an entrepreneurial venture will decide not to seek VC financing (i.e., demand-side selection).

Interestingly, the fact that $N$ is high (i.e., that more companies could potentially be on the market for $\mathrm{VC}$ ) does not mean that $n$ (i.e., the deal flow for $\mathrm{VC}$ ) will also be high. The deal flow for VC is, in fact, the outcome of two opposing forces. On the one hand, an increase in $N$ implies that a greater number of entrepreneurs is expected to be above any given threshold of $I$. On the other hand, equation (2) shows that an increase in $N$ causes an increase in the equilibrium threshold to enter in the market for VC. For large values of $N$, these two opposing forces offset each other, and the deal flow converges to a constant, as shown below in Proposition 1.

Proposition 1: As the number $(N)$ of potential competitors for VC increases, the expected deal flow $(E[n \mid N])$ converges to the following:

$$
\lim _{N \rightarrow \infty} E[n \mid N]=-\ln (s)
$$


Proof: The expected deal flow, conditioned on the number of potential entrants, is given by $E[n \mid N]=N\left(1-G\left(\widetilde{I}_{N}\right)\right)$, where $\widetilde{I}_{N}$ is obtained by solving equation (1) for a given number of potential entrants $N$. Substituting the expression for $G(\widetilde{I})$ obtained from equation (1), we obtain the following:

$$
E[n \mid N]=N\left(1-G\left(\widetilde{I}_{N}\right)\right)=N\left(1-\left(\frac{s}{\widetilde{I}_{N}}\right)^{\frac{1}{N-1}}\right)=N\left(1-\exp \left(\frac{\ln (s)-\ln \left(\widetilde{I}_{N}\right)}{N-1}\right)\right)
$$

The limit as $N \rightarrow \infty$ of the previous expression is given by the following:

$$
\lim _{N \rightarrow \infty} E[n \mid N]=\lim _{N \rightarrow \infty} N\left(1-\exp \left(\frac{\ln (s)-\ln \left(\widetilde{I}_{N}\right)}{N-1}\right)\right)=\lim _{N \rightarrow \infty} N\left(\frac{\ln \left(\widetilde{I}_{N}\right)-\ln (s)}{N-1}\right)=-\ln (s)
$$

where, in the last step, we exploit the fact that because $G(i)$ is strictly increasing for $i$ in $(0,1)$ and $\mathrm{G}(1)=1, \lim _{N \rightarrow \infty} \widetilde{I}_{N}=1$.

Proposition 1 proves an important property of the endogenous two-step selection process between entrepreneurs and a $\mathrm{VC}$ investor: the number of firms that decide to enter the market for $\mathrm{VC}$ does not increase indefinitely as the number of potential competitors $N$ increases. Put differently, this means that when $N$ is large, the number of companies in the market for VC does not depend upon $N$. The importance of this result can be better understood through the following equation:

$$
\underbrace{\operatorname{Pr}[\text { Firm receives VC }]}_{1 / N}=\underbrace{\operatorname{Pr}[\text { Firm seeks VC] }}_{\begin{array}{c}
\text { Demand-side selection } \\
\frac{E[n] N}{N}
\end{array}} \cdot \underbrace{\operatorname{Pr}[\text { Firm receives VC|Firm sought VC }]}_{\begin{array}{c}
\text { Supply-side selection } \\
\frac{1}{E[n \mid N]}
\end{array}}
$$

The unconditioned probability that any given firm receives $\mathrm{VC}$, which is simply given by $1 / N$, clearly declines as the number of potential competitors $(N)$ increases. What Proposition 1 shows us is that when $N$ is large, the reason why this probability declines is demand-side selection, i.e., more and more firms decide not to look for VC in the first step. In fact, of the two terms on the right-hand side of equation (4), the first goes to 0 with $N$ while the second converges to a finite value (i.e., $\left.-\ln (s)^{-1}\right)$. In thin $\mathrm{VC}$ markets (i.e., large $N$ ), the demand-side selection becomes more severe than the supplyside selection. Accordingly, the main reason why entrepreneurs in thin VC markets do not obtain VC financing is that they rationally decide to stay out of such markets.

Proposition 1 proves that when VC is in extremely scarce supply, the availability of VC in a certain market affects the probability that an entrepreneurial firm seeks VC financing but not the probability that it receives it, conditional on participation in the market for VC. This line of argumentation leads to the following testable hypothesis: 
Hypothesis 2. The thinness of VC in a geographical area does not affect the probability of actual receipt of financing, conditional on participation in the market for VC (i.e., supply-side selection).

\section{Location choice in thin VC markets}

In the model illustrated in the previous Section, we assume that the number of potential competitors $N$ is exogenously determined. This also means that an entrepreneur does not have the choice, in our model, to relocate to a region in which the market is less thin. This assumption is well supported in the literature, where the home-bias of entrepreneurs is well documented (e.g., Mueller and Morgan 1962) and greater than the home bias of employees (e.g., Michelacci and Silva 2007, Dahl and Sorenson 2009). We will also provide empirical support for this argument in the Section about Robustness Checks and Additional Evidence.

However, at least in principle, one might wonder whether location choices by entrepreneurs may offset any difference in thinness between neighboring regions. We may obtain some insight about this matter using the model illustrated in the previous Section. Assume that two neighboring regions exist: Region 1 and Region 2. Each region has one VC operating at a local scale (i.e., for simplicity we assume that no cross-regional investments are possible). The two regions have, respectively, $N 1=N$ and $N 2=N+\Delta N$ entrepreneurs who could enter into their local markets for VC. If no entrepreneur can relocate from one region to the other, we will find the "autarchic" equilibrium using the model illustrated in the previous Section.

Now, let us assume that one of the entrepreneurs in Region 2 may decide to relocate to Region 1, bearing additional relocation costs. Will the entrepreneur relocate from Region 2 to Region 1? The answer clearly depends on the parameters of the model, and finding a general solution to this problem is beyond the scope of this work. However, a general feature of the solution can be illustrated using simple economic intuition. If the entrepreneur had $I_{j}<\widetilde{I}_{N 1+1}$, she would not move from Region 2 because if she did, she would bear the relocation costs and still not be in the market for VC in Region 1. Because we have shown in Equation (2) that $\widetilde{I}_{N}$ is increasing in $N$, we may conclude that regardless of $\Delta N$ and for any value of the relocation cost and $I_{j}$, the incentive to relocate decreases with $N$. This article is protected by copyright. All rights reserved. 
Intuitively, if both regions present a thin local $\mathrm{VC}$ market, the entrepreneurs will be less likely to relocate from one to the other regardless of any difference in thinness between the two and even if relocation costs are relatively small. To some extent, market thinness exacerbates relocation costs through the same mechanism by which it exacerbates entry costs: by reducing the likelihood that a benefit is reaped once the cost is incurred. These results suggest that in a country with a thin VC market, even if its regions differ in market thinness, entrepreneurs are unlikely to base their location choices on the availability of VC.

\section{Number of founders and demand-side selection}

Our model, as presented in the previous Section, does not delve into the size of entrepreneurial teams. Because NTBFs are rarely founded by a single individual and instead are often created by entrepreneurial teams (e.g., Colombo and Grilli 2010), in this section, we extend the model to study the extent to which the number of founders affects the decision of companies to enter into the market for $\mathrm{VC}$. As we mentioned above, the decision to compete for $\mathrm{VC}$ entails a search cost $(s)$ that is significant for the founder. Intuitively, to the extent to which this cost is divisible, it would be less relevant if more founders could share it.

We can formalize this idea as follows. We will assume that each entrepreneurial venture is created at time $t=0$ by $m$ identical founders. Each founder gets a fraction $1 / m$ of the value of the company and has a disutility of the effort in the form $\alpha \cdot \tau^{\beta}$, where $\tau$ is the time spent by the founder in pursuing all the activities that are required for a firm that self-selects into the market for VC. The convexity of the disutility of effort is captured by $\beta>1$. The convexity of the disutility of effort captures the managerial overload of founders (e.g., Acemoglu et al. 2003). Because entrepreneurs tend to work long hours (Parasuraman et al. 1996), we can expect founders to exhibit a very convex disutility function (i.e., $\beta \gg 1$ ).

We will assume that the decision to actively seek $\mathrm{VC}$ requires from each founder an effort that is

equal to $\tau=\frac{T(1+\gamma)^{m-1}}{m}$, where $T$ is the time that would be required for this task from a single entrepreneur (i.e., $m=1$ ) and $\gamma$ measures the extent to which subdividing the task among $m>1$ This article is protected by copyright. All rights reserved. 
founders entails coordination costs. We will normalize the parameter $\alpha$ such that $s$ is the search cost when $m=1$. We can then rewrite Equation (1) from the perspective of each of the $m$ founders of any of the $N$ companies as follows:

$$
\tilde{I}=s \cdot \varphi(m) \cdot G(\tilde{I})^{1-N}
$$

Where $\varphi(m)=\frac{(1+\gamma)^{\beta(m-1)}}{m^{\beta-1}}$ is the parameter that determines the effect of distributing the task among the $m$ founders. It is easy to show that $\varphi(m)<1$ when $\ln (1+\gamma)<\frac{\beta-1}{\beta \cdot m} .^{2}$

In other words, to the extent to which the inefficiency of distributing the task across the different founders (i.e., $\gamma$ ) is sufficiently low, a greater number of founders has the same effect as a lower search cost. ${ }^{3}$ Under these conditions, we may expect that an increase in the number of founders leads more companies to self-select into the market for VC.

In our framework, the number of founders $(m)$ affects the propensity of a firm to be in the market for $\mathrm{VC}$ under the assumption that it does not influence the overall benefit of VC financing, namely $I_{j}$. Put differently, in our theoretical model the number of founders will only affect the demand-side selection and not the supply-side selection. After the first step of the selection process is finalized and the search cost has been spent (and is hence sunk), the supply-side selection is conducted independently from $m$. As we will discuss in the Section on the empirical methodology of this paper, this feature of the theoretical model will be empirically tested in order to verify that the number of founders can indeed represent a viable exclusion restriction in the empirical model.

\section{SAMPLE AND DESCRIPTIVE STATISTICS}

In this Section, we present the empirical setting of our work. First, we describe the Italian VC market in the early 2000s and explain why it is an appropriate setting in which to test our theoretical

\footnotetext{
${ }^{2}$ First, we can observe that $\varphi(1)=1$. Next if we take the first derivative of $\varphi(m)$ we obtain: $\varphi^{\prime}(m)=-\frac{\varphi(m)}{m}(\beta-1-$ $\beta \cdot m \cdot \ln (1+\gamma))$, which is negative when $\ln (1+\gamma)<\frac{\beta-1}{\beta \cdot m}$.

${ }^{3}$ Corresponding to the average number of founders in our sample $(m=2.4)$ and to a quadratic function for the disutility of effort $(\beta=2)$, the critical value of the inefficiency of the task distribution is $\gamma<23.5 \%$.
}

This article is protected by copyright. All rights reserved. 
model. Second, we provide a description of the sampling process through which we collected surveybased data on 190 Italian NTBFs in 2004. Finally, we operationalize the key variable of this study, a venture's decision to enter the market for $\mathrm{VC}$, and we report some descriptive statistics.

\section{The Italian VC market in the early $2000 \mathrm{~s}$}

NTBFs operating in Italy at the beginning of the 2000s are an ideal set of candidates to test our theoretical predictions. First, in the late 1990s and early 2000s, Italy was characterized by a thin VC market. The Italian financial system was extremely bank-based. The ratio of the market value of listed firms to GDP was $48.2 \%$ in 2001 (source: CONSOB, 2002) compared with $138.0 \%$ in the USA and $151.4 \%$ in the UK (source: OECD, Financial Market Trends, October 2004). The difference was even larger at the beginning of the 1990s. For instance, Rajan and Zingales (2003) show that in 1990, the ratio of the market value of listed firms to GDP was $13 \%$ in Italy, whereas it was $54 \%$ in the USA and $84 \%$ in the UK. Conversely, the ratio of bank deposits to GDP was $40 \%$ in Italy, $33 \%$ in the UK and only $19 \%$ in the USA. Early stage equity financing from professional investors was almost nonexistent until the mid-1990s and then increased considerably in the late nineties, reaching a peak of 540 million $€$ in 2000 , equal to $0.046 \%$ of GDP (source: AIFI, the Italian Association of Venture Capital and Private Equity Investors). Starting in 2001, early stage equity financing experienced a dramatic decline and, in 2004, there were only 50 investments in 36 companies, for a total invested amount of 23 million $€$ or $0.002 \%$ of GDP. Therefore, there were relatively few VC investors that could potentially finance the NTBFs in our sample. ${ }^{4}$

A second reason why Italy is an interesting environment to test our hypotheses is that significant variations can be observed in the development of its $\mathrm{VC}$ market across regions. According to AIFI, $88 \%$ of the VC money in 2004 was invested in the North of the country, $5 \%$ in the Center, and only $4 \%$ in the South. Even when accounting for differences in the volume of economic activity among these regions (see the next Section), the disproportionate distribution of VC remains remarkable.

\footnotetext{
${ }^{4}$ Financing conditions have improved in more recent years: between 2007 and 2012, VC investment averaged $0.004 \%$ of GDP. In 2014, VC investments were $€ 43$ million in 84 VC-backed companies (source: AIFI). For further details on the early years of the Italian VC industry, see Bertoni et al. (2006).
}

This article is protected by copyright. All rights reserved. 
These cross-regional differences in the availability of $\mathrm{VC}$ will allow us to observe the selection process between investors and investee companies under different degrees of market thinness.

Finally, we have both anecdotal and empirical confirmation of the tendency of investors and portfolio firms to be located close to each other in our setting. In particular, we analyzed the local specialization of investments in Italy during the period 1980-2005 using the VICO dataset (Bertoni and Martì 2011), a dataset especially designed to study VC activity in Europe. We found that in first round investments, the median distance in Italy was $47 \mathrm{~km}$; therefore, approximately half of the portfolio companies are located within $50 \mathrm{~km}$ of the investor. This figure is consistent with the work by Bertoni et. al. (2016), documenting that in Europe, $48.6 \%$ of invested companies are less than $50 \mathrm{~km}$ away from their VC investors. This evidence confirms the localized nature of VC investments in Italy during the period under scrutiny. Looking at regions as defined by the NUTS classification (Eurostat 2015), we found that $62 \%$ of firms have at least one investor located in the same NUTS2 region, ${ }^{5}$ while this percentage only increases to $66 \%$ when looking at the NUTS1 level and drops to $33 \%$ at the NUTS3 level. On average, in Italy, a NUTS2 region has an area of $16,410 \mathrm{~km}^{2}$ (Eurostat 2015), which corresponds to a circular radius of $38.2 \mathrm{~km}$. Considering that for two random points in a circle, the average distance is $0.905^{*}$ radius (i.e., $34.6 \mathrm{~km}$ in our case) and the median distance is $0.891 *$ radius (i.e., $34.0 \mathrm{~km}$ in our case), ${ }^{6}$ this figure is not too distant from the $47 \mathrm{~km}$ mentioned above and is closer than what we would obtain using NUTS1 and NUTS3 regions, which have an approximate radius of $78.2 \mathrm{~km}$ and $16.7 \mathrm{~km}$, respectively. Given this evidence, we opted for the NUTS2 level as the most reasonable geographical level for our analysis.

\footnotetext{
${ }^{5}$ We have repeated a similar analysis using investments extracted from a commercial database: Thomson One. In order to attribute a NUTS2 region to each VC investor and target company, we first translated the textual information about their ZIP code, city and country provided by Thomson One into numerical information on the latitude and longitude coordinates. Looking at first-round investments between 1980 and 2005 in Italy, we found that 52\% of firms were located in the same NUTS2 region where the investor resides and 59\% in the same NUTS1 region. Again, this figure corroborates the view of a rather localized nature of VC investments and complies well with the other figures illustrated in the main text.

${ }^{6}$ The average distance between two random points in a circle is radius $* 128 /(45 * \pi)$. In order to calculate the median distance, for which there is no closed-end formula, we used Monte-Carlo simulation. We randomly generate 1,000 points inside of a circle and calculate the distance between each of the 499,000 resulting pairs to calculate the median distance. We replicate this process for 10,000 replications and estimate that the $95 \%$ confidence interval for the median distance is radius $*(0.891 \pm 0.001)$.
}

This article is protected by copyright. All rights reserved. 


\section{Sampling process and sample composition}

The sample used in this study is extracted from the RITA (Research on Entrepreneurship in Advanced Technologies) directory developed at Politecnico di Milano (for a detailed description, see Appendix A). The RITA directory is the most comprehensive information source presently available on Italian NTBFs and provides an accurate representation of the country's population of entrepreneurial growth-oriented ventures in high-tech sectors at the beginning of 2004 (see also Colombo and Grilli 2005, 2010). It is important to stress that because of the criteria used for inclusion of a firm in the RITA directory, the database is unlikely to include lifestyle companies, firms created purely for tax-saving objectives, non-growth-oriented firms and other scarcely entrepreneurial acts. Therefore, it is quite unlikely that potential candidates for VC investment in Italy in 2004 were excluded from the RITA directory. In defining an NTBF, RITA adheres to the gold-standard definition originally offered by Arthur D. Little (1977). Specifically, sample firms were younger than 25 years at the time of the survey, were owner-managed at their foundation and remained independent up to $1 / 1 / 2004$ (i.e., they were not controlled by another business organization even though other organizations might hold minority stakes) and operated in the following high-tech manufacturing and services sectors: advanced materials; avionics; biotechnology and pharmaceuticals; computers; electronic components; electronic publishing; Internet and multimedia content; optical, medical and electronic instruments; process automation equipment; robotics; software; telecommunication equipment; and telecommunication services.

In the first semester of 2004, a questionnaire was sent to the contact persons of RITA directory firms either by fax or by e-mail. The first section of the questionnaire asked detailed questions about the human capital characteristics of a firm's founders. The second section contained questions concerning the characteristics of the firms, including the number of employees at the time of foundation, the firm's active search for VC, and whether and when it was invested by VC. The answers to the questionnaire were checked for internal consistency and were compared with information obtained from public sources (i.e., firms' websites and annual reports). In several cases, phone or face-to-face follow-up interviews were conducted with the firm's owner-managers. This This article is protected by copyright. All rights reserved. 
final step was crucial to obtain missing data and ensure that data were reliable. ${ }^{7}$ Finally, data on firm size and access to VC financing were cross-checked with those available from commercial sources (e.g., AIDA, i.e., the Italian fine-grained version of the Amadeus-Bureau Van Dijk database, and VenturExpert). ${ }^{8}$

The sample used in the present work consists of the 190 NTBFs that participated in the 2004 RITA survey and for which we were able to build a complete dataset for the variables of interest. This sample enables us to analyze a representative sample of the population of Italian growth-oriented high-tech entrepreneurial ventures existing in 2004, with very fine-grained information at the founder and firm levels. The $\chi^{2}$ tests indicate that the distribution of the sample firms across industries and geographic areas is not different from the corresponding distribution of the population of the 1,974 RITA firms from which the sample was drawn $\left(\chi^{2}(4)=1.00\right.$ and $\chi^{2}(3)=3.05$, respectively).

We report the distribution of sample NTBFs by industry and foundation date in Table 1. As noted above, the distribution of the sample closely mirrors the underlying population of Italian NTBFs. Most firms in our sample are in the Internet \& Multimedia (30.5\%) and Software $(28.4 \%)$ sectors. Conversely, very few entrepreneurial ventures are in Robotics \& Automation $(8.9 \%)$ or in Biotech \& Pharmaceutics (4.2\%). NTBFs were predominantly created in the second half of the $1990 \mathrm{~s}$.

[Table 1 about here]

\section{High-tech entrepreneurial ventures in the market for VC}

The key variable of our analysis is the decision of NTBFs to enter the market for VC. We define an NTBF as being in the market for VC if i) it has ever actively sought equity capital from a VC investor or ii) it has ever entered into a formal or informal negotiation with a VC investor. Similarly to

\footnotetext{
${ }^{7}$ In only 3 cases, none of the founders was part of the owner-manager team at the time of the survey.

8 This was another important step in order to gauge the reliability of the respondents to our survey. As to the VC investments, documented discrepancies between survey and official data were extremely limited. Some differences were instead found between the number of employees indicated by RITA respondents and the number of employees officially declared by the firm to the Chambers of Commerce. These differences are probably due to the fact that some of the workers in these startups have atypical working contracts, which means that while they effectively work for the company according to RITA respondents, they do not formally enter into the headcount for official purposes. Nevertheless, the correlation between the two series $(0.87)$ is extremely high.
} 
Eckhardt et al. (2006), but focusing only on equity (or equity-like) capital, we asked the entrepreneurial ventures in our sample whether they had ever actively sought equity capital from a professional VC investor and if they had ever entered into a negotiation.

Table 1 reports the distribution by industry and age of the firms that entered the market for VC and those that ultimately received financing. Only 103 (54.21\% of the ventures) sample firms had entered the market for VC. Put differently, almost half of our sample (45.79\%) is composed of entrepreneurial growth-oriented high-tech ventures that never considered actively looking for a VC investor. Out of the 103 ventures in the market for VC, 42 firms $(22.11 \%$ of the sample) received VC financing. Table 1 also presents the distribution of firms that entered into the market for $\mathrm{VC}$ and those that ultimately received financing as a function of the availability of VC in the region where an NTBF is located. Among the 103 firms that entered the market for $\mathrm{VC}, 41.7 \%$ are located in regions with higher availability of VC (i.e., the third tertile of the variable VC INVESTORAreakt (Balassa), see Table 2 for the definition). A similar pattern applies to the firms that actually received financing (47.6\% of VC-backed firms are located in regions with higher availability of VC). Our econometric investigation will aim at determining whether this greater percentage of investees in areas with higher availability of $\mathrm{VC}$ (other than a mere selection rule by VC investors) is driven, in our context, by a self-selection-out process by firms in the first step.

\section{Empirical methodology}

\section{Econometric strategy}

To control for unobserved heterogeneity that may influence both steps of the selection process, we resort to a Heckman two-step probit model. The first equation models the probability of a venture being in the market for $\mathrm{VC}$, and the second equation captures a firm's likelihood of being financed by a $\mathrm{VC}$, conditional on being in the market for $\mathrm{VC}$. The independent variables of these equations include founder- and firm-specific characteristics and other environmental covariates. The two equations are jointly estimated via maximum likelihood (ML) to control for the unobserved heterogeneity that 
affects both a venture's probability of being in the market for $\mathrm{VC}$ and its likelihood of receiving a VC investment, allowing more consistent estimates of the parameters of this second outcome equation. ${ }^{9}$

\section{Description of variables included in the models}

Table 2 presents the definition of the explanatory variables included in our model.

[Table 2 about here]

Table 3 illustrates some basic descriptive statistics and the correlation matrix of the dependent and explanatory variables of both equations. We computed variance inflation factors (VIF) for all the regressors to assess whether multicollinearity is a problem in our regression models. All our independent variables are well below the rule-of-thumb threshold of 10 (Hair et al. 1995), and the mean VIF is 1.39 , which leads us to conclude that collinearity is unlikely to be an issue in our analysis.

[Table 3 about here]

To cope with possible biases resulting from endogeneity and reverse causality, the independent variables introduced into the model are measured at time of firm foundation, which minimizes the risk of endogeneity with the two steps of the selection process. The key variable at the basis of our hypotheses is the level of VC availability in the geographical area in which an NTBF is located. We proxy the degree of availability of $\mathrm{VC}$ in the geographical area using VC INVESTORAreakt, which is inserted in both equations. We compute the variable in two different ways. Firstly, we computed it as a Balassa specialization index at the local level (Balassa et al. 1989), which is calculated as follows (see also Colombo and Grilli 2005, 2010): VC INVESTORAreakt $($ Balassa $)=V C A k t / A_{k t}$. VCAkt is the fraction of high-tech VC deals in region $k$ (NUTS2) over the country total (source: AIFI). $A_{k t}$ is the fraction of active companies operating in high-tech sectors in region $k$ out of the country total (source:

\footnotetext{
${ }^{9}$ As a robustness check, we also estimate the two equations separately with the inclusion in the second step of the inverse Mills ratio (IMR) computed from the selection equation. The results of this two-step procedure are consistent with those of the ML estimation and are available from the authors upon request.
}

This article is protected by copyright. All rights reserved. 
Infocamere database-Italian Chambers of Commerce). Both the numerator and the denominator are measured in the year $t$ of foundation of the NTBF. ${ }^{10}$

Secondly, we calculate VC INVESTORAreakt (Ratio), which has a similar meaning and interpretation as VC INVESTORAreakt (Balassa) but is calculated using a different formula: the ratio between the number of $\mathrm{VC}$ investments and the number of high-tech active firms in the region $k$ where the NTBF operates at its year $t$ of foundation. This latter variable is meant to be an alternative proxy of the availability of $\mathrm{VC}$ at the regional (NUTS2) level. We will also discuss two alternative choices for the base year in the calculation of VC INVESTORAreakt (Balassa) and VC INVESTORAreakt (Ratio) in the Section on Robustness Checks and Additional Evidence.

According to Hypothesis 1, VC INVESTORAreakt should positively affect a venture's decision to enter into the market for VC. In other terms, a thin VC supply should curb ventures' willingness to look for VC. Hypothesis 2 instead predicts that the impact of this variable on the second step should be negligible.

To control for confounding factors, we include in the model a wide range of covariates capturing the basic characteristics of the NTBFs and their founders and the socio-economic characteristics of the geographical areas in which they operate.

\section{Characteristics of the entrepreneurial venture at foundation}

The model includes the size of the firm measured by the natural logarithm of the number of employees (excluding founders) at foundation (LnSize). DInnoMotive reflects the importance of innovative motivations for the creation of the venture. The questionnaire provided information about the main motive of each individual founder for the firm's creation, where respondents could choose among innovative purposes, defensive motivations (e.g., unemployment) or the need for autonomy. DInnoMotive is a dummy variable that indicates whether all the members of the entrepreneurial team declared that the wish to exploit an innovative technology was the main motive for the creation of the

\footnotetext{
${ }^{10}$ Official disaggregated data about VC investment at the geographical level before 1997 are not available, mostly because of the near non-existence of the sector (see the dedicated Section on the 'The Italian VC market in the early 2000s'). Accordingly, a value equal to zero for the variable is assigned to those firms founded before that year. In this respect, note that only 6 firms out of the 42 VC-backed ventures in our sample received VC funding before 1997, and excluding these 6 NTBFs from our empirical analysis leaves our findings unaltered.
}

This article is protected by copyright. All rights reserved. 
firm. DebtOnEquity is the ratio of debt to total equity at the firm's foundation and proxies the firm's availability of external capital besides equity.

\section{Entrepreneurs' human capital}

Founders' human capital plays a primary role in determining NTBF performance (Gimeno et al. 1997, Colombo and Grilli 2005). We include in the model's specification several variables related to the human capital of entrepreneurs, such as their education and work experience. We have a strong advantage compared with recent studies related to founding teams (e.g., Hmieleski et al. 2013; Rauch and Rijsdijk 2013) because we are able to collect information on the human capital of the whole entrepreneurial team for each firm rather than data only on the principal founder. The founder's human capital variables are constructed by summing the years of experience of all the firm's founders. ${ }^{11}$ We distinguish between years of university-level education in economic and managerial fields $(E c o E d u c)$ and years of university-level education in scientific and technical fields (TechEduc). Notably, but largely predictably given the firms' high-tech nature, entrepreneurial teams appear to be characterized by relatively low levels of economic education (mean of EcoEduc: 0.841 years) and relatively high levels of technical education (mean of TechEduc: 5.323 years).

To gauge founders' work experience at start-up time, we measure the sum of the number of years of work experience of the components of the entrepreneurial team before the firm's foundation (WorkExp). Then, we also proxy the managerial experience of the founding team with a dummy variable capturing whether any of the entrepreneurs had prior managerial experience in a mediumlarge company (with more than 100 employees) before the firm's foundation (DManager). The presence of founders with previous managerial experience is relatively rare: only $11.4 \%$ of founding teams had at least one member with this type of previous managerial experience.

Opposing forces apply to the effect of founders' human capital variables on an NTBF's propensity to enter the market for VC. In particular, human capital has both a wealth effect and a capability effect

\footnotetext{
11 We have also considered different non-linear alternatives for measuring founders' human capital. Specifically, we replicated our estimates using the following measures of human capital within the founding team: the maximum level, the average level, the logarithm of the total level, the presence of a given characteristic (i.e., we recoded variables into dummies). The results are consistent with those reported here and are available from the authors upon request.
}

This article is protected by copyright. All rights reserved. 
(Colombo and Grilli 2005). According to the wealth effect, the total amount of founders' human capital can negatively impact the probability of entering the market for VC: an increase in the internal resources of the founders may result in a lower need to search for external capital. According to the capability effect, highly skilled entrepreneurs are reputed to be more likely to base their entrepreneurial ventures on innovative and profitable business ideas (Venkataraman 1997, Klepper 2001, Shane 2000, 2003; Ucbasaran et al. 2008), which, on average, require more resources compared to less valuable ideas (Åstebro and Bernhardt 2003), a phenomenon that is particularly pronounced in high-tech sectors (Colombo et al. 2004). Accordingly, a positive effect of founders' human capital on a firm's decision to enter the market for VC should be expected. In addition to these considerations, certain characteristics of founders' human capital may release a signal regarding the quality of the entrepreneurial team and, in general, positively influence VC decisions.

\section{Size of the entrepreneurial team}

In addition to the total amount of human capital, we also include the natural logarithm of the size of the entrepreneurial team (LnFounders). This variable plays a key role in the identification of the two-step model because we use it as an exclusion restriction between the two equations. The identifying assumption is that LnFounders founders affect the likelihood of securing VC only through the probability that the company seeks VC (after controlling for the human capital of the founding team and the observable quality of the venture).

The size of the entrepreneurial team positively affects the decision to enter the market for $\mathrm{VC}$ for more than one reason. First, the entry costs for actively seeking VC are more easily absorbed by a large entrepreneurial team, as shown in the theoretical Section. Secondly, a high number of founders may also mean more social capital, which reduces the cost of contacting an investor who is potentially interested in the firm.

In contrast, after controlling for the quality and heterogeneity of the competences and capabilities of the founding team (proxied in our model by variables related to the levels of education and previous working experience), there is no strong theoretical reason why the number of founders should significantly affect the probability of receiving VC, and no empirical study in the field seems This article is protected by copyright. All rights reserved. 
to suggest the relevance of this relationship. To the extent that this true and that no unobserved heterogeneity links the number of founders to the decision of VCs, this condition acts as an exclusion restriction that enables us to differentiate the two equations and increase the efficiency of the estimated model, which would otherwise only be identified based on the non-linearity between the selection and outcome functions (Heckman and Navarro-Lozano 2004). Our choice of using the measure of size of the entrepreneurial team as an exclusionary restriction is also consistent with other closely related studies. For example, Hsu (2004) uses firm size at foundation as an exclusionary restriction in a Heckman two-step binary analysis related to $\mathrm{VC}$ dynamics. In his analysis, the first stage focuses on multiple vs single VC offers and the second stage investigates determinants of the highest pre-money valuation. He uses the logarithm of employees at firm foundation as an exclusionary restriction. The absence of a strong correlation between the number of founders of a start-up and VC investments is also supported in other empirical contexts. For example, Wasserman (2017), in his analysis of 16,500 entrepreneurs and 6,130 VC-backed and non-VC backed startups founded in the US between 2005 and 2012, empirically documents how the variable "number of founders" is very scarcely correlated with VC-related variables such as "Angel/VC on board attracted executive hires" (pairwise correlation equal to 0.00161) and "VCs invested in last round of financing" (0.0502). Other recent important examples in this stream of literature do not even contemplate the possibility that this variable could exert any impact on VC investors' decision criteria (see for example Sørensen 2007 and Bernstein et al. 2017).

In addition, we also run some empirical checks to test the reliability of our choice. In particular, we have also inserted the variable LnFounders in the second step of the Heckman two-step procedure. The insertion of this variable does not alter in any way the main findings of our analysis, and, most importantly, it proves to be an exclusionary restriction not only on a theoretical basis but also on empirical grounds. In fact, the coefficient of the variable is statistically significant in the first step, whereas it is insignificant in the second step. Furthermore, we run a probit model on the receipt of VC financing (on all sample firms and on firms in the market for $\mathrm{VC}$ ), again finding no significant effect 
of the number of founders. These findings are also consistent with previous work in the $\mathrm{VC}$ literature (see, e.g., Colombo and Grilli 2010 for evidence related to the same context considered here).

Due to these theoretically and empirically based motives, notwithstanding unavoidable caveats that may exist in this respect (see the Limitations Section), we repute the variable LnFounders to represent a valid exclusionary restriction in the Heckman two-step probit model we perform.

\section{Geographical level controls}

We computed several measures as proxies of different dimensions of local development at the regional (NUTS2) level. They are listed below:

- an inverse Herfindahl index measuring the industrial heterogeneity in the high-tech segment at the local level: $H_{j t}=1-\sum_{i} x_{i j t}^{2}$. Where $x_{i j t}$ is the ratio between the number of active firms in the high-tech sector $i$ (see industry classification of Table 1), region $j$, and year $t$ and the total number of active firms in high-tech sectors in region $j$ and year $t$ (source: Infocamere databaseItalian Chambers of Commerce);

- $\quad$ the number of Automatic Teller Machines (ATMs) per square kilometer as a proxy of the level of regional bank development (sources: Infostat database-Bank of Italy and Eurostat);

- GDP per capita as a proxy of average wealth at the regional level (source: Eurostat);

- the number of patents per square kilometer as a proxy of innovativeness at the regional level (source: Eurostat);

- the number of inhabitants per square kilometer to control for population density (source: Eurostat);

- the number of firms per square kilometer as a proxy of firms' density at the regional level (source: Eurostat).

Given the very high correlation of these variables, we decided to perform a factor analysis to reduce multicollinearity and extract the few factors that explain most of the variance. Because the inverse Herfindahl index is uncorrelated with the other variables, we decided to exclude it from the factor analysis and instead include the variable as a stand-alone regressor in the Heckman two-step probit model. After the factor analysis and a VariMax rotation, we computed two factors that explain This article is protected by copyright. All rights reserved. 
$78.7 \%$ of the aggregated variance in the original variables. The first factor (GeoFactor 1 ) has higher factor loadings on the variables capturing firms' density, the number of patents per square kilometer and inhabitants per square kilometer, and can be interpreted as a proxy for local economic development. The second factor (GeoFactor2) has higher coefficients on the variables related to the number of ATMs per square kilometer and GDP per capita and can be interpreted as a proxy for local financial development.

\section{Other controls}

Finally, we include as an additional control variable the natural logarithm of the firm's age at the moment of the survey (LnAge). Because our measure of a firm's positioning in the market for VC is constant over time, LnAge controls for the fact that older ventures may be more likely to have looked for $\mathrm{VC}$ at least once in their life. Moreover, this variable allows us to control for potential recall bias (Coughlin 1990), which may arise from the retrospective nature of our survey. Because recall bias depends on the distance in time between the event and the survey (Huber and Power 1985, Stewart et. al 1987), this variable should help to alleviate this potential problem by capturing any time trend in the propensity to respond affirmatively. ${ }^{12}$

\section{RESULTS}

Table 4 shows the estimates of the selection equation on the determinants of firms' positioning in the market for $\mathrm{VC}$ and the outcome equation on the determinants of the investment decision by $\mathrm{VC}$ investors. Columns (1) and (2) refer to the basic Heckman two-step probit model, columns (3) and (4) report the estimates of the model augmented with the geographical level controls, and columns (5) and 6) report the estimates of the model augmented with a first alternative measure for the local availability of VC. The results can be summarized as follows.

[Table 4 about here]

\footnotetext{
${ }^{12}$ In order to further reduce concerns about potential recall bias, we also conducted two additional robustness checks. First, we included the squared term of LnAge among the regressors because this term may help in capturing and controlling for the non-linear effects of time passing. Second, we estimated our model by excluding older firms (i.e., firms founded before 1985), which are the most likely to be affected by a potential recall bias. The results are consistent with those reported in the paper; we do not report them here for the sake of parsimony, but they are available from the authors upon request.

This article is protected by copyright. All rights reserved.
} 
Consistent with Hypothesis 1, we find that the thickness of VC supply in the same geographical area of an NTBF is positively related to the likelihood that an NTBF enters the VC market. This finding is in line with the theoretical model, suggesting that scarce supply deters entrepreneurial ventures from seeking VC financing. When all other variables are set at their median, the estimated probability of entering into the market for VC increases by one-fifth when VC INVESTORAreakt (Balassa) increases from the $10^{\text {th }}$ to the $90^{\text {th }}$ percentile. Hypothesis 2 is confirmed as well: the availability of $\mathrm{VC}$ does not affect the probability of receiving $\mathrm{VC}$, given that the $\mathrm{NTBF}$ is in the market for VC. ${ }^{13}$ Therefore, we find that a scarce supply of $\mathrm{VC}$ has a sizeable negative effect on the demand-side self-selection of companies but does not significantly affect the probability of receiving a $\mathrm{VC}$ investment for an entrepreneurial venture that decided to enter the market for VC.

With regard to control variables, several results are worth noting. The size of an NTBF has a positive impact on both the probability of being in the market for $\mathrm{VC}$ and the probability of receiving a $\mathrm{VC}$ investment. The innovative motivation behind the creation of the firm has a significant positive effect on both dependent variables. In other words, the degree of perceived novelty of the business idea drives both the entrepreneur's and the investor's decisions. The debt-to-equity ratio does not appear to significantly affect the two steps. ${ }^{14}$

The size of the entrepreneurial team positively affects the probability of looking for VC and does not significantly shape the probability of receiving it. This result confirms our expectations: larger teams can share the burden of entry costs and may have easier access to $\mathrm{VC}$ thanks to their superior social capital, but later, VC selection decisions are not significantly influenced by the size of the entrepreneurial team.

\footnotetext{
${ }^{13}$ As a robustness check, we also used the variable VC INVESTORArea $($ Balassa) as a further exclusion restriction, i.e., we estimated the model including this variable in the selection equation but not in the outcome equation. The results are similar to the ones reported.

${ }^{14}$ Please note that the debt to equity ratio is measured at time of foundation and that only two NTBFs in our sample received VC financing at foundation. This is likely to alleviate endogeneity concerns. Note, however, that as a further robustness check, we estimated the same model excluding these two firms. We obtained similar results.
}

This article is protected by copyright. All rights reserved. 
Among other factors, geographical-level controls do not significantly affect either the first or the second step, ${ }^{15}$ while, conversely, entrepreneurs' human capital is found to influence the investigated phenomena. In fact, economic-related education and managerial experience appear to significantly determine both the positioning of an NTBF in the market for $\mathrm{VC}$ and the probability of the firm receiving VC financing. Entrepreneurs with a high level of education in economics and management subjects, as well as some managerial experience, will have lower information, entry and negotiation costs as well as more acquaintances with $\mathrm{VC}$ investors compared with teams of entrepreneurs that are mostly technical. This evidence is consistent with the view that economic and managerial competencies reduce the information costs of the entrepreneurs as well as the cognitive distances between them and financial investors, thus engendering a lower level of reciprocal misunderstanding and, in turn, lowering negotiating costs. This evidence also suggests that VC investors highly value the managerial skills possessed by a founding team. In contrast, technical education is found to exert a negative impact on the probability of entering the market for $\mathrm{VC}$, while it does not appear to exert any highly significant impact on the VC decision (i.e., the coefficient of TechEduc is positive in the second step but statistically significant at the $10 \%$ level only in column 4 ). Lastly, we may notice that work experience of the entrepreneurial team is found to negatively affect the probability of an NTBF entering the VC market, suggesting the potential relevance of the wealth effect of human capital (Colombo and Grilli 2005).

The significant LR test of independence between the two equations indicates that it is necessary to jointly consider the two steps of the $\mathrm{VC}$ financing process, as there are unobserved factors explaining both the probability of looking for $\mathrm{VC}$ and the probability of receiving $\mathrm{VC}$. The positive correlation of the error terms of the two equations further supports our theoretical model, according to which firms are more likely to be in the market for $\mathrm{VC}$ the higher their $I_{j}$ (which is an unobservable factor) is, and at the same time, a high $I_{j}$ will increase the likelihood that they receive VC financing.

\footnotetext{
${ }^{15}$ We also run a series of Heckman two-step probit models where the geographical level controls composing the two factors are instead inserted as individual regressors. The results (available upon request) confirm the scarce statistical incidence.
}

This article is protected by copyright. All rights reserved. 


\section{ROBUSTNESS CHECKS AND ADDITIONAL EVIDENCE}

\section{Entrepreneurs' location choice}

In our model, we considered the location choice by an entrepreneur in a thin $\mathrm{VC}$ market to be independent from the local availability of VC. The tendency of entrepreneurs to found their companies in their home regions is a general trend that is well documented by the literature and is known as local- or home- bias (see, e.g., Michelacci and Silva 2007, Dahl and Sorenson 2009). In addition, Dahl and Sorenson (2012) also find that new ventures perform better (i.e., survive longer and generate greater annual profits and cash flows) when they are located in regions in which their founders have lived longer.

Moreover, we argued theoretically that home bias is particularly likely to hold in thin VC markets even if different regions of the country differ in terms of access to $\mathrm{VC}$, provided all these regions can be considered to be thin (i.e., high $N$ ). This assumption means that, on average, individuals in a thin VC market who are located in areas in which VC is thinner-than-average should not relocate to regions in which $\mathrm{VC}$ is thicker-than-average (yet still thin). In other words, we assume that in a thin market, entrepreneurs are considered to be fairly reluctant to found their firms in locations different from their present location just because of differences in VC thinness.

Given the importance of this assumption, we also examine this issue empirically in a sub-sample of firms included in the main analysis. The first evidence that no substantial VC-driven migration is taking place in our sample comes from the simple observation of firm distribution in Table 1. If entrepreneurs relocated to obtain better funding conditions, we would expect to see fewer startups in regions with low availability of $\mathrm{VC}$ than in regions with high availability of VC. However, Table 1 shows that the distribution of sample firms is not significantly different $\left(\chi^{2}(2)=3.83\right)$ from a uniform distribution among regions with low, medium and high availability of VC. Moreover, the areas with the highest number of startups (74 firms, corresponding to $38.9 \%$ of the sample) are the ones with the medium, not the highest, availability of VC (64 firms, 33.7\%). This evidence suggests that if a VCdriven migration occurs, its effect is not visible at the macro level.

This article is protected by copyright. All rights reserved. 
At the micro level, we may argue that if entrepreneurs moved towards the regions with more abundant VC, we should observe that startups that relocated from one region to another should be on the market for VC more often than those that did not (because being on the market for VC was one of the reasons why they relocated). To test this hypothesis, we collected the statute of incorporation (which is signed by each founder in front of a public notary and deposited in the local Chamber of Commerce) of as many sample firms as possible and retrieved detailed data on the region and province of birth for each founder (source: Telemaco repository- Italian Chambers of Commerce). We found the birth place of 171 founders, for a total of 56 sample firms. Then, we operationalized two dummy variables indicating whether i) at least one of the founders was born in a different region (corresponding to NUTS2 level) from the one in which the firm was founded (d_l moved) and ii) the majority of founders were born in the same region in which the firm was founded (d_moststayed). Then, we checked whether the occurrences of $d_{-} 1$ moved $=1$ and $d \_$moststayed $=1$ were correlated to the fact that the firm had ever sought or received VC financing. The results are presented in Table 5. First of all, and in line with the macro-evidence previously highlighted, the results show that migration flows are limited: less than half (42.9\%) of the firms have founders who were born in another region, and $89.3 \%$ of firms have a majority of founders who are local. Second, we classify firms into three VC statuses: firms that did not seek VC, firms that sought VC but did not obtain it, and firms that sought and received VC. Two $\chi^{2}$ tests show that the relative frequency of these VC statuses is not affected by the two location dummies. In other words, we find no evidence that founding teams in which one or the majority of the founders relocated are more likely to seek or obtain VC. This lends further support to the idea that, for those few entrepreneurs who decide to move, $\mathrm{VC}$ does not seem to be the main reason behind this choice.

[Table 5 about here]

\section{Alternative measures of availability of VC in the geographical area}

Our main measure of the availability of $\mathrm{VC}$ in the geographical area, VC INVESTORAreakt (Balassa), is a typical specialization index computed at the local level. This variable captures the 
relative density of $\mathrm{VC}$ investments in a region, controlling for the relative density of investable companies. This same construct could be captured with different variables and, hence, we have replicated our analyses using several alternative measures. First, as already mentioned, we used a similar variable (VC INVESTORAreakt (Ratio)) measuring the number of VC investments in a region weighted by the number of high-tech firms located in the same region. The results concerning INVESTORAreakt (Ratio) are illustrated in Table 4, columns 5 and 6, and totally conform to those obtained using INVESTORAreakt (Balassa).

Both the variables VC INVESTORAreakt (Balassa) and VC INVESTORAreakt (Ratio) are computed using values measured at the time of the foundation of the NTBF. However, different choices are equally possible in this respect. Specifically, for both VC INVESTORAreakt (Balassa) and VC INVESTORAreakt (Ratio), we computed an average and cumulated version. The average version is obtained using the mean of $\mathrm{VC}$ investments in the region and the mean of high-tech active firms in the region over the entire period (1980-2003) covered in our dataset. The cumulated version uses the cumulated number of investments and cumulated number of high-tech active firms from the first year in the time-span to the year $t$ of foundation of the focal NTBF. The formal operationalization of these variables is presented in Appendix B. We used all these measures alternatively, obtaining results (available upon request) that are similar to the ones presented above, thus confirming that the relative local specialization in $\mathrm{VC}$ investments positively and significantly affects only the probability of looking for $\mathrm{VC}$ but not the probability of actual receipt of $\mathrm{VC}$ financing.

\section{DISCUSSION}

\section{Contributions}

In this work, we highlight that the scarcity of local VC negatively affects the likelihood of an NTBF actively seeking VC and that this demand-side selection dominates the supply-side selection made by VC investors. Our study makes important contributions to two streams of literature. 
First of all, the findings of our analysis are expected to contribute to the literature on entrepreneurial finance by formally analyzing the conditions under which demand-side selection characterizes a VC market and documenting its occurrence in a specific national context. Few VC markets on a global scale are reputed to have reached the maturity stage, which increases the interest of this work and calls for replication efforts in different geographical and institutional contexts than the one investigated here. Overall, our analysis highlights how the decision of an NTBF not to seek $\mathrm{VC}$ is the result of an ex-ante cost-benefit evaluation, and the final outcome is that the $\mathrm{VC}$ market is characterized by a significant self-selection-out by the potential targets, who anticipate that search costs are harder to recover when competition for $\mathrm{VC}$ is fierce. We add to the limited literature on the reasons for refusing to seek VC by highlighting that, in addition to cultural and socioemotional wealth motives, economic considerations may explain such a behavior as a purely rational strategy on the part of entrepreneurs.

By shedding some light on the functioning of thin VC markets, this paper also offers policy makers interesting insights into the entrepreneurship domain. Specifically, we argue that high entry costs and small expected benefits from entry into the market for VC may determine self-selection-out in thin VC markets. In doing so, we emphasize how helping such VC markets to grow will require interventions on the VC-demand side, possibly ranging from the legal environment (e.g., bankruptcy reforms) to cultural domains (e.g., stimulating an entrepreneurial Silicon Valley attitude, see Armour and Cumming 2006). More interestingly, our analysis also shows that VC supply-side thinness is responsible (at least to some extent) for slow demand-side dynamics, justifying public policies aimed at sustaining the $\mathrm{VC}$ supply to trigger a virtuous cycle between the two sides of the market. Recent contributions have highlighted a positive role of government-sponsored programs in the VC industry to the extent that policy intervention is willing to complement and increase private investment rather than play a leading role in the choice of the targets and the active management of investments (e.g., Brander et al. 2010, 2015; Bertoni and Tykvová 2015, Grilli and Murtinu 2014, 2015). The set-up of hybrid public-private funds, with the public actor playing a facilitating role rather than a leading one, may indeed increase the thickness of VC markets by acting as a pole of attraction for the supply of This article is protected by copyright. All rights reserved. 
(internationally qualified) private VC investors. Whereas this study highlights that both VC investors' and entrepreneurs' strong localization biases are important characteristics of entrepreneurial ecosystems, the increase in internationalization of the VC industry (Guler and Guillén 2010) demonstrates that a more even distribution of $\mathrm{VC}$ investments could occur in the long term, also because of regulatory actions such as the pan-European VC passport (EU Regulation No. 345/2013, see also EY 2014).

From this perspective, we show that breaking the vicious cycle and solving the typical chickenegg paradox of nascent markets (i.e., deal flow is scarce because of a shortage of VC, and, at the same time, VC is poorly developed because of the limited observed deal flow) may require coordinated actions between demand and supply of VC. Furthermore, in addition to the aforementioned demandoriented interventions, supply-side programs might be relevant. In this domain, among the actions that may be envisaged, our contribution highlights that policy measures aiming at rapidly attracting specific experienced VC investors in specific geographical areas, thus ameliorating the scarcity of the local VC supply, could represent an essential step toward leveraging the demand side and the number of potentially attractive deals. The successful Yozma program implemented in Israel during the 1990s represents a paradigmatic example in this respect (Avnimelech and Teubal 2006, Lerner 2009). The program included a co-investment scheme between public and private operators that provided VC investors with a strong upside incentive (i.e., a 5-year option to buy the government's share at cost). The incentive was designed to attract and remunerate higher-quality investors and 'became a catalytic program' (Avnimelech and Teubal 2006, p. 1489) by creating a critical mass of VC investments. In this respect, our analysis suggests that market thinness may be more effectively reduced by policies that aim to concentrate existing VC investors in a relatively narrow geographical area rather than build a geographically dispersed VC market.

\section{Limitations}

Our study does have some limitations. First of all, our research design does not allow us to include those firms that did not survive until 2004. This represents a potential caveat of the empirical 
analysis that is inherent to almost any survey-based study. Nevertheless, we believe that if this survivorship bias exists, its influence on our results should be mitigated by the presence of opposite forces at work. On the one hand, NTBF failure rates are likely to decrease with access to VC finance because VC-backed firms allegedly benefit from greater endowment of financial and other resources (Puri and Zarutskie 2012). Hence, if this is the case, the impact of those independent variables related to the venture's success (e.g., founders' human capital, innovative motivation) on both the venture's willingness to look for $\mathrm{VC}$ - and eventual access to it - are likely to be larger than what is shown by our empirical analysis. On the other hand, opposite biases might also exist. Successful VC-backed ventures are more likely to be acquired than their non-VC-backed peers (see again Puri and Zarutskie 2012) as trade sales are an important exit mechanism for VC investors (especially in the Italian VC context where the equity market is thin, see the dedicated Section). Moreover, VC-backed firms might be more risk-prone than non-VC-backed ones and have an inherently lower likelihood of survival (Manigart and Van Hyfte 1999).

Secondly, we resort to a time-invariant variable to capture a firm's propensity to seek VC. A timevarying measure would allow the analysis of when during a firm's life, and under which circumstances, a firm actively seeks VC. This analysis may be hindered by the fact that measuring a time-varying version of our dependent variable may prove to be particularly difficult in practice because it requires entrepreneurs to remember in which periods they were actively seeking VC financing and in which ones they were not. Our preliminary attempts to collect a time-varying measure showed that while entrepreneurs remember if they actively sought $\mathrm{VC}$, it is much more difficult for them to precisely locate this event in a specific time period.

Third, our identification strategy in the Heckman two-step probit model relies on the assumption that no omitted variable exists that jointly determines the size of the founding team as well as the probability that the company secures VC. While our choice is corroborated by several tests and is well supported by the literature in the $\mathrm{VC}$ field, the presence of unobservable heterogeneity across firms may exist in this respect, even for firms with the same human capital of founders and observable quality characteristics.

This article is protected by copyright. All rights reserved. 
Finally, we cannot exclude that thin VC supply translates into low quality of the investors operating in the market: low competition among operators may enable the survival of less efficient investors, which may be less attractive for entrepreneurial ventures. Moreover, a very restricted number of investors translates into limited heterogeneity in investors' characteristics and into a lower probability of finding a compatible match for entrepreneurs (according to Gans and Stern 2010, this aspect is crucial in determining the thinness of a market). The reduced (perceived) quality and compatibility may further discourage start-ups from entering the VC market. Although all these effects are reflected in the thinness of the VC market, further analysis would be needed to disentangle the relative importance of these underlying mechanisms.

\section{Future research}

All the above-cited limitations also represent room for future improvements in the analysis of the self-selection-out dynamics of entrepreneurial ventures in thin VC markets. Our study also calls for replication in different geographical and institutional contexts than the one investigated here. The analysis of the specific and idiosyncratic characteristics of nascent VC markets can lead to the individuation of specific national and institutional features that may help policy makers better design and tailor their normative efforts.

From a theoretical perspective, we have not analyzed which specific ventures enter into the market for VC and which ones choose to stay out. In other words, we have not measured how much of the self-selection-out process involves potentially good ventures worthy of attention from VC investors. Such analysis poses more than one challenge (e.g., determining, based essentially on expost performance, what is an ex-ante potentially good target), but it would certainly represent an interesting addition to our study.

\section{CONCLUSIONS}

This paper attempts to reconcile two apparently contradictory pieces of evidence regarding the functioning of $\mathrm{VC}$ markets. On the one hand, $\mathrm{VC}$ is found to exert a beneficial impact on the 
performance of entrepreneurial ventures. However, on the other hand, many entrepreneurial ventures do not actively seek VC when the market is thin: approximately half of the NTBFs in our sample never actively sought VC. Our paper attempts to reconcile this apparent contradiction and offers a theoretical explanation of why, under certain specific market conditions, a substantial self-selectionout by entrepreneurial ventures may occur. We develop a simple two-step selection model between $\mathrm{VC}$ and entrepreneurial ventures that starts from the intuition that a scarce presence of VC investors in the market, combined with the existence of entry costs faced by entrepreneurial ventures, increases the fraction of companies that will not actively seek $\mathrm{VC}$ in the first place. When the market becomes extremely thin, only a very small fraction of firms may still be willing to incur these costs of being in the market for VC. This demand-side selection is more severe if the market is thinner, and for very thin markets, it will dominate supply-side selection. Theoretical predictions are investigated using a sample of high-tech entrepreneurial ventures that operate in an undeveloped VC market. The empirical results document that shortage of supply has an effect on the (two-stage) selection process, given that a company that does not enter into the market for $\mathrm{VC}$ will never receive it. This fact influences the actual pairs (company and investor) in the VC market. Through this analysis, we show that the thinness of the VC supply can play a major role in shaping the selection process between VC investors and high-tech entrepreneurial ventures. In this respect, this study enlarges our understanding of the functioning of $\mathrm{VC}$ markets. 


\section{References}

Acemoglu, D., Aghion, P., Zilibotti, F., 2003. Vertical integration and distance to frontier. Journal of the European Economic Association 1, 630-638.

Armour, J., Cumming, D., 2006. The legislative road to Silicon Valley. Oxford Economic Papers 58, 596-635.

Arthur D. Little, 1977. New technology-based firms in the United Kingdom and the Federal Republic of Germany. Wilton House: London.

Åstebro, T., Bernhardt, I., 2003. Start-up financing, owner characteristics, and survival. Journal of Economics and Business 55, 303-319.

Avnimelech, G., Teubal, M., 2006. Creating venture capital industries that co-evolve with high tech: Insights from an extended industry life cycle perspective of the Israeli experience. Research Policy 35, 1477-1498.

Balassa, B., Marcus N., 1989. Revealed comparative advantage in Japan and the United States. Journal of International Economic Integration 2, 8-22.

Bank of England, 2001. Financing of technology-based small firms. Second Report, Domestic Finance Division, Bank of England.

Baum, J.A.C., Silverman, B.S. 2004. Picking winners or building them? Alliance, intellectual, and human capital as selection criteria in venture financing and performance of biotechnology startups. Journal of Business Venturing 19, 411-436.

Berger, A.N., Udell, G.F. 1998. The economics of small business finance: The roles of private equity and debt markets in the financial growth cycle. Journal of Banking and Finance 22, 613-673. 
Bernstein, S., Giraud, X., Townsend, R.R. 2016. The impact of venture capital monitoring. The Journal of Finance 71, 1591-1622.

Bernstein, S., Korteweg, A., Laws, K. 2017. Attracting early-stage investors: Evidence from a randomized field experiment. The Journal of Finance 72, 509-538.

Bertoni, F., Colombo, M.G., Croce, A., Piva, E., 2006. A review of the venture capital industry in Italy. In Gregoriou, G.N., Kooli, M., Kraeussl R. (Eds.), Venture capital in Europe. Elsevier: Amsterdam.

Bertoni, F., Colombo, M.G., Quas, A. 2015. The patterns of venture capital investment in Europe. Small Business Economics 45, 543-560.

Bertoni, F., D’Adda, D., Grilli L. 2016. Cherry-picking or frog-kissing? A theoretical analysis of how investors select entrepreneurial ventures in thin venture capital markets. Small Business Economics 46, 391-405.

Bertoni F, Martí J. 2011. Financing Entrepreneurial Ventures in Europe: The Vico Dataset. SSRN Scholarly Paper, Social Science Research Network, Rochester, NY. Available at: http://papers.ssrn.com/abstract=1904297.

Bertoni, F., Tykvová, T. 2015. Does governmental venture capital spur invention and innovation? Evidence from young European biotech companies. Research Policy, 44, 925-935.

Brander, J.A., Du, Q., Hellmann, T., 2015. The effects of government-sponsored venture capital: International evidence. Review of Finance 19, 571-618.

Brander JA, Egan E, Hellmann T. 2010. Government sponsored versus private venture capital: Canadian evidence. In Lerner, J., Schoar, A., (Eds.), International differences in entrepreneurship, National Bureau of Economic Research, University of Chicago Press, Chicago, IL, US. 
Carlsson, B., Acs, Z.J., Audretsch, D.B., Braunerhjelm, P., 2009. Knowledge creation, entrepreneurship, and economic growth: a historical review. Industrial and Corporate Change 18, 1193-1229.

Carpenter, R.E., Petersen, B.C., 2002. Capital market imperfections, high-tech investment, and new equity financing. Economic Journal 112, F54-F72.

Carpentier, C., Suret, J.M., 2006. Some evidence of the external financing costs of new technology based firms in Canada. Venture Capital 8, 227-252.

Chen, H., Gompers, P., Kovner, A., Lerner, J., 2010. Buy local? The geography of venture capital. Journal of Urban Economics 67, 90-102.

Chiappori P-A, Salanié B. 2016. The econometrics of matching models. Journal of Economic Literature 54, 832-861.

Colombo, M.G., Delmastro, M. and Grilli, L., 2004. Entrepreneurs' human capital and the start-up size of new technology-based firms. International Journal of Industrial Organization 22, 1183-1211.

Colombo, M.G., Grilli, L., 2005. Founders' human capital and the growth of new technology-based firms: a competence based view. Research Policy 34, 795-816.

Colombo, M.G., Grilli, L., 2010. On growth drivers of high-tech start-ups: the role of founders' human capital and venture capital. Journal of Business Venturing 25, 610-626.

CONSOB, 2002. Annual Report. Commissione Nazionale per le Società e la Borsa.

Coughlin, S.S., 1990. Recall bias in epidemiologic studies. Journal of Clinical Epidemiology 43, 8791.

Cressy, R., Olofsson, C., 1997. European SME financing: an overview. Small Business Economics 9, $87-96$. 
Cumming, D.J., Dai, N., 2010. Local bias in venture capital investments. Journal of Empirical Finance $17,362-380$.

Dahl, M.S., Sorenson, O., 2009. The embedded entrepreneur. European Management Review 6, 172181.

Dahl, M.S., Sorenson, O., 2012. Home sweet home: Entrepreneurs' location choices and the performance of their ventures. Management Science 58, 1059-1071.

Devigne, D., Vanacker, T., Manigart, S., Paeleman, I., 2013. The role of domestic and cross-border venture capital investors in the growth of portfolio companies. Small Business Economics 40, 553573.

Eckhardt, J.T., Shane, S., Delmar., F., 2006. Multistage selection and the financing of new ventures. Management Science 52, 220-232.

Eisenmann, T.R., 2015. What we learned from 200 startups who raised $\$ 360$ million. Mimeo (https://docsend.com/view/p8jxsqr).

European Parliament, 2012. Potential of Venture Capital in the European Union. Directorate General for Internal Policies. Policy Department A: Report on Economic and Scientific Policy Industry, Research and Energy, Brussels.

Eurostat, 2015. Regions in the European Union - Nomenclature of Territorial Units for Statistics NUTS 2013/EU-28. Eurostat Manual and Guidelines, Publications Office of the European Union, Luxembourg.

EY, 2014. Adapting and Evolving, Global Venture Capital Insights and Trends 2014 Report. (http://www.ey.com/Publication/vwLUAssets/Global_venture_capital_insights_and_trends_2014/\$FI LE/EY_Global_VC_insights_and_trends_report_2014.pdf).

Gans, J.S., Stern, S., 2010. Is there a market for ideas? Industrial and Corporate Change 19, 805-837. 
Gimeno, J., Folta, T., Cooper, A., Woo, C., 1997. Survival of the fittest? Entrepreneurial human capital and the persistence of underperforming firms. Administrative Science Quarterly 42, 750-783.

Gompers, P.A., Lerner, J., 2004. The venture capital cycle. MIT Press: Cambridge, Massachusetts.

Grilli, L., Murtinu, S., 2014. Government, venture capital and the growth of European high-tech entrepreneurial firms. Research Policy 43, 1523-1543.

Grilli, L., Murtinu, S., 2015. New technology-based firms in Europe: Market penetration, public venture capital and timing of investment. Industrial and Corporate Change 24, 1109-1148.

Groh, A.P., von Liechtenstein, H., Lieser, K., 2010. The European venture capital and private equity country attractiveness indices. Journal of Corporate Finance 16, 205-224.

Guler, I., Guillén, M.F., 2010. Institutions and the internationalization of US venture capital firms. Journal of International Business Studies 41, 185-205.

Hair, J.F. Jr., Anderson, R. E., Tatham, R.L., Black, W. C., 1995. Multivariate data analysis. 3rd eds., Macmillan Publishing Company: New York.

Hall, J., C.W. Hofer, 1993. Venture capitalists' decision criteria in new venture evaluation. Journal of Business Venturing 8, 25-42.

Heckman, J.J., Navarro-Lozano, S., 2004. Using matching, instrumental variables, and control functions to estimate economic choice models. Review of Economics and Statistics 86, 30-57.

Himmelberg, C.P., Petersen, B.C., 1994. R\&D and internal finance: a panel study of small firms in high-tech industries. Review of Economics and Statistics 76, 38-51.

Hmieleski, K.M., Corbett, A.C., Baron, R.A., 2013. Entrepreneurs' improvisational behavior and firm performance: A study of dispositional and environmental moderators. Strategic Entrepreneurship Journal 7, 138-150. 
Hochberg, Y., Ljungqvist, A., Lu, Y., 2007. Whom you know matters: Venture capital networks and investment performance. The Journal of Finance 62, 251-301.

Hsu, DH., 2004. What do entrepreneurs pay for venture capital affiliation? The Journal of Finance 59, $1805-1844$.

Huber, G.P., Power, D.J., 1985. Retrospective reports of strategic-level managers: Guidelines for increasing their accuracy. Strategic Management Journal 6, 171-180.

Italian Association of Venture Capital and Private Equity Investors (AIFI). Annual statistics.

Kane, T., 2010. The Importance of Startups in Job Creation and Job Destruction. Kauffman Foundation Research Series: Firm Formation and Economic Growth (http://www.kauffman.org/uploadedfiles/firm_formation_importance_of_startups.pdf).

Klepper, S., 2001. Employee startups in high-tech industries. Industrial and Corporate Change 10, 639-674.

Kon, Y., Storey, D.J., 2003. A theory of discouraged borrowers. Small Business Economics 21, 37-49.

Lerner, J., 2009. Boulevard of broken dreams: why public efforts to boost entrepreneurship and venture capital have failed--and what to do about it. Princeton University Press: Princeton, New Jersey.

Lutz, E., Bender, M., Achleitner, A.K., Kaserer, C., 2013. Importance of spatial proximity between venture capital investors and investees in Germany. Journal of Business Research 66, 2346-2354.

Mäkelä, M.M., Maula, M.V.J. 2000. Attracting cross-border venture capital: the role of a local investor. Entrepreneurship \& Regional Development 20, 237-257.

Mason, C.M., Harrison, R.T., 2001. 'Investment readiness': a critique of government proposals to increase the demand for venture capital. Regional Studies 35, 663-668. 
Manigart, S., Van Hyfte, M., 1999. Post-investment evolution of venture backed companies. In Reynolds, P., Bygrave, W., Manigart, S., Mason, C., Meyer, G., Sapienza, H.J., Shaver, K. (Eds.), Frontiers of entrepreneurship research. Babson College: Wellesley, Massachusetts.

Michelacci, C., Silva, O., 2007. Why so many local entrepreneurs? Review of Economics and Statistics 89, 615-633.

Mindruta D, Moeen M, Agarwal R. 2016. A two-sided matching approach for partner selection and assessing complementarities in partners' attributes in inter-firm alliances. Strategic Management Journal 37, 206-231.

Mueller, E., Morgan, J.N., 1962. Location decisions of manufacturers. American Economic Review $52,204-217$.

OECD. Financial market trends. No. 106, Volume 2014/2.

Parasuraman, S., Purohit, Y., Godshalk, V., 1996. Work and family variables, entrepreneurial career success, and psychological well-being. Journal of Vocational Behavior 48, 275-300.

Petty, J.S., Gruber, M., 2011. 'In pursuit of the real deal': a longitudinal study of VC decision making. Journal of Business Venturing 26, 172-188.

Puri, M., Zarutskie, R., 2012. On the lifecycle dynamics of venture-capital- and non-venture-capitalfinanced firms. Journal of Finance 67, 2247-2293.

Ragozzino, R., Reuer, J.J., 2011. Geographic distance and corporate acquisitions: signals from IPO firms. Strategic Management Journal 32, 876-894.

Rajan, R.G., Zingales L., 2003. The great reversals: the politics of financial development in the twentieth century. Journal of Financial Economics 69, 5-50.

Rauch, A., Rijsdijk, S.A., 2013. The effects of general and specific human capital on long-term growth and failure of newly founded businesses. Entrepreneurship Theory and Practice 37, 923-941. 
Roth, A.E. 2007. Repugnance as a constraint on markets. Journal of Economic Perspectives 21, 37-58.

Shane, S., 2000. Prior knowledge and the discovery of business opportunities. Organization Science $11,448-469$.

Shane, S., 2003. A general theory of entrepreneurship. Edward Elgar Publishing: Northampton, Massachusetts.

Sørensen, M., 2007. How smart is smart money? A two-sided matching model of venture capital. Journal of Finance 62, 2725-2762.

Sorenson, O., Stuart, T.E., 2001. Syndication networks and the spatial distribution of venture capital investments. American Journal of Sociology 106, 1546-1588.

Stewart, W.F., Tonascia, J.A., Matanoski, G.M., 1987. The validity of questionnaire-reported work history in live respondents. Journal of Occupational Medicine 29, 795-800.

Tyebjee, T.T., Bruno, A.V., 1984. A model of venture capitalist investment activity. Management Science 30, 1051-1066.

Ucbasaran, D., Westhead, P., Wright, M., 2008. Opportunity identification and pursuit: does an entrepreneur's human capital matter? Small Business Economics 30, 153-173.

Venkataraman, S., 1997. The distinctive domain of entrepreneurship research: an editor's perspective. In Katz, J., Brockhaus, R. (Eds.), Advances in entrepreneurship, firm emergence and growth. JAI Press: Greenwich, Connecticut.

Wasserman, N. (2017). The throne vs. the kingdom: founder control and value creation in startups. Strategic Management Journal 38, 255-277.

Zacharakis, A.L., Meyer, G.D., 1998. A lack of insight: do venture capitalists really understand their own decision process? Journal of Business Venturing 13, 57-76. 
Zacharakis, A.L., Meyer, G.D., 2000. The potential of actuarial decision models: can they improve the venture capital investment decision? Journal of Business Venturing 15, 323-346.

Zacharakis, A.L., Shepherd, D.A., 2001. The nature of information and overconfidence on venture capitalists' decision making. Journal of Business Venturing 16, 311-332. 


\section{Tables and figures}

Figure 1: Timeline of the model

\begin{tabular}{ccc}
$\mathrm{t}=0$ & $\mathrm{t}=1$ \\
\hline N entrepreneurial ventures are created & $\begin{array}{l}\text { Each venture decides whether or not to } \\
\text { be in the market for } \mathrm{VC} \text { and to incur an } \\
\text { entry cost } s .\end{array}$ & $\begin{array}{c}\text { vC chooses which entrepreneurial } \\
\text { venture to invest among those that } \\
\text { actively sought it. }\end{array}$
\end{tabular}

Table 1: Distribution of NTBFs according to their positioning in the market for VC and eventual VC financing by industry, foundation year and geographical area

\begin{tabular}{ccccccc}
\hline \hline & & & & & \\
& Total & & In the market for VC & \multicolumn{2}{c}{ VC Financed } \\
\hline \hline No. & $\%$ & No. & $\%$ & No. & $\%$
\end{tabular}

\section{Industry}

$\begin{array}{lcccccc}\text { Biotech \& Pharmaceutics } & 8 & 4.2 & 4 & 3.9 & 2 & 4.8 \\ \text { Electronic publishing } & 11 & 5.8 & 8 & 7.8 & 6 & 14.3 \\ \text { Internet \& Multimedia } & 58 & 30.5 & 38 & 36.9 & 19 & 45.2 \\ \text { ICT Manufacturing } & 42 & 22.1 & 23 & 22.3 & 8 & 19.0 \\ \text { Robotics \& Automation } & 17 & 8.9 & 6 & 5.8 & 2 & 4.8 \\ \text { Software } & 54 & 28.4 & 24 & 23.3 & 5 & 11.9\end{array}$

\section{Foundation Year}

$\begin{array}{ccccccc}1980-1984 & 18 & 9.5 & 6 & 5.8 & 2 & 4.8 \\ 1985-1989 & 37 & 19.5 & 20 & 19.4 & 9 & 21.4 \\ 1990-1994 & 36 & 18.9 & 15 & 14.6 & 4 & 9.5 \\ 1995-1999 & 71 & 37.4 & 42 & 40.8 & 16 & 38.1 \\ 2000-2003 & 28 & 14.7 & 20 & 19.4 & 11 & 26.2\end{array}$

Availability of VC (by tertile of VC INVESTORAreakt (Balassa))

\begin{tabular}{lrrrrrr} 
Low $\left(1^{\text {st }}\right.$ tertile $)$ & 52 & 27.4 & 25 & 24.3 & 9 & 21.4 \\
Medium $\left(2^{\text {nd }}\right.$ tertile $)$ & 74 & 38.9 & 35 & 34.0 & 13 & 31.0 \\
High $\left(3^{\text {rd }}\right.$ tertile $)$ & 64 & 33.7 & 43 & 41.7 & 20 & 47.6 \\
& & & & & & \\
Total & $\mathbf{1 9 0}$ & $\mathbf{1 0 0 . 0}$ & $\mathbf{1 0 3}$ & $\mathbf{1 0 0 . 0}$ & $\mathbf{4 2}$ & $\mathbf{1 0 0 . 0}$ \\
\hline \hline
\end{tabular}


Table 2: Definition of variables

\section{Description}

\section{Selection variable}

InVCMarket

\section{Outcome variable}

VCFinancing

\section{Explanatory variables}

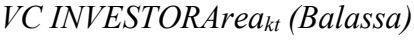

VC INVESTORArea It $_{\text {(Ratio) }}$

LnSize

LnFounders

DInnoMotiv

DebtOnEquity

WorkExp

TechEduc

EcoEduc

DManager

GeoFactor1

GeoFactor2

InverseHerfindhal

LnAge
Dummy equal to one if the firm has ever been "in the market for VC"

Dummy equal to one if the firm has ever received $\mathrm{VC}$ financing

A Balassa-type specialization index given by $V C A_{k t} / A_{k t} . V C A_{k t}$ is the fraction of hightech VC deals in region $k$ (NUTS2) over the country total (source: AIFI). $A_{k t}$ is the fraction of active companies operating in high-tech sectors in the region $k$ out of the country total (source: Infocamere database-Italian Chambers of Commerce). Both the numerator and the denominator are measured in the year $t$ of foundation of the NTBFs.

Ratio between the number of VC investments (source: AIFI) in the region (at NUTS2 level) and the number of high-tech active firms in the region (source: Italian Chamber of Commerce) in the year $t$ of foundation of the NTBFs.

Logarithm of the number of full time equivalent employees at the founding time, excluding active founders.

Logarithm of the number of founders.

Dummy equal to one if all firms' founders declared that the wish to exploit an innovative technology was the main motive for the creation of the firm.

Debt to equity ratio at founding time.

Sum of the number of years of work experience of founders before firm's foundation.

Sum of the number of years of scientific and/or technical education of founders at university level.

Sum of the number of years of economic and/or managerial education of founders at university level.

Dummy variable that equals one if within the founding team there are one or more individuals who, prior to the establishment of the new firm, had a managerial position in a company with a number of employees greater than 100 .

First factor resulting after factor analysis and VariMax rotation, with higher scoring coefficients of the density of firms, patents per square kilometer and inhabitants per square kilometer (source: Eurostat).

Second factor resulting after factor analysis and VariMax rotation, with higher scoring coefficients of the number of ATMs per square kilometer and GDP per capita (source: Bank of Italy and Eurostat).

An inverse Herfindahl index measuring industrial heterogeneity in the high-tech segment at the local level: $\mathrm{H}_{\mathrm{jt}}=1-\sum_{\mathrm{i}} \mathrm{x}_{\mathrm{ijt}}^{2}$. Where $\mathrm{x}_{\mathrm{ijt}}$ is the ratio between the number of active firms in the high-tech sector $i$, region $j$, year $t$, and the total number of active firms in high-tech sectors in region $j$, year $t$.

Logarithm of the age of the firm in 2004. 
Table 3: Descriptive statistics and correlation matrix

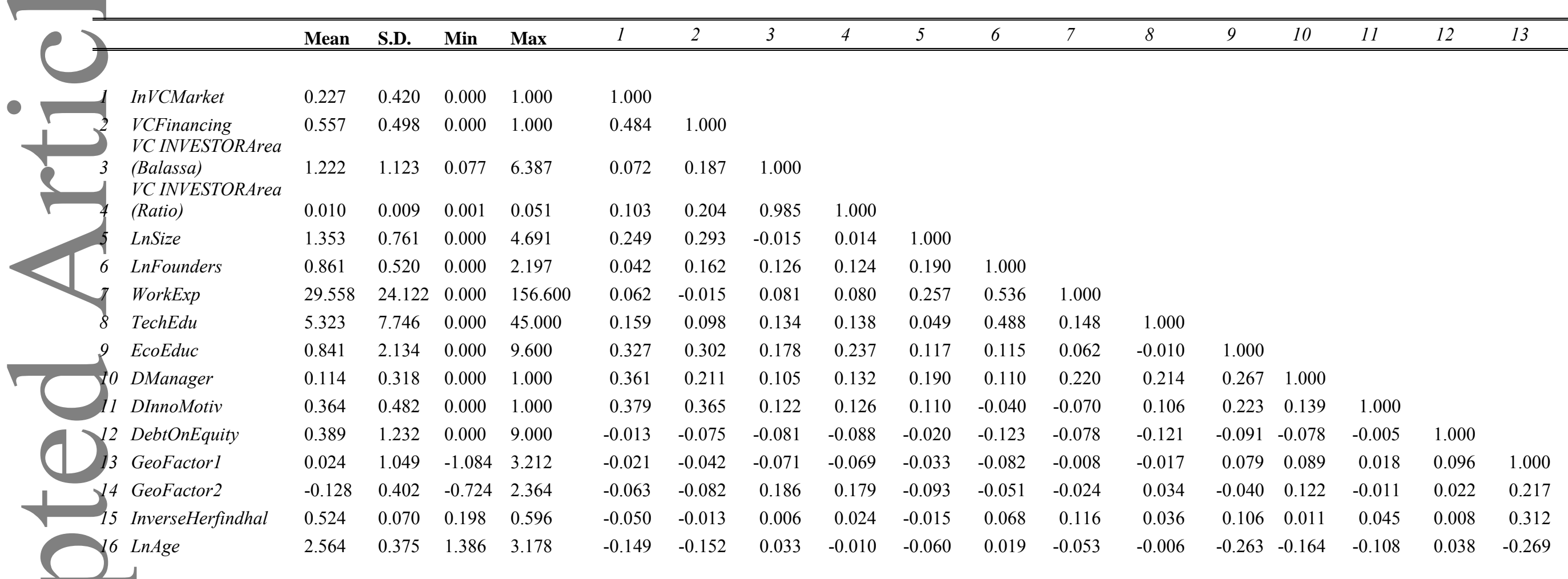

Legend. Significance level: ${ }^{*} p<0.10,{ }^{* *} p<0.05,{ }^{* * *} p<0.01$.

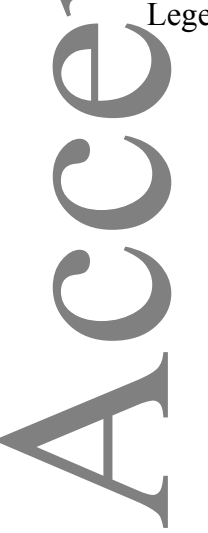

This article is protected by copyright. All rights reserved. 
Table 4 - Selection and outcome equation: the choice of being in the market for VC and the likelihood of obtaining VC financing

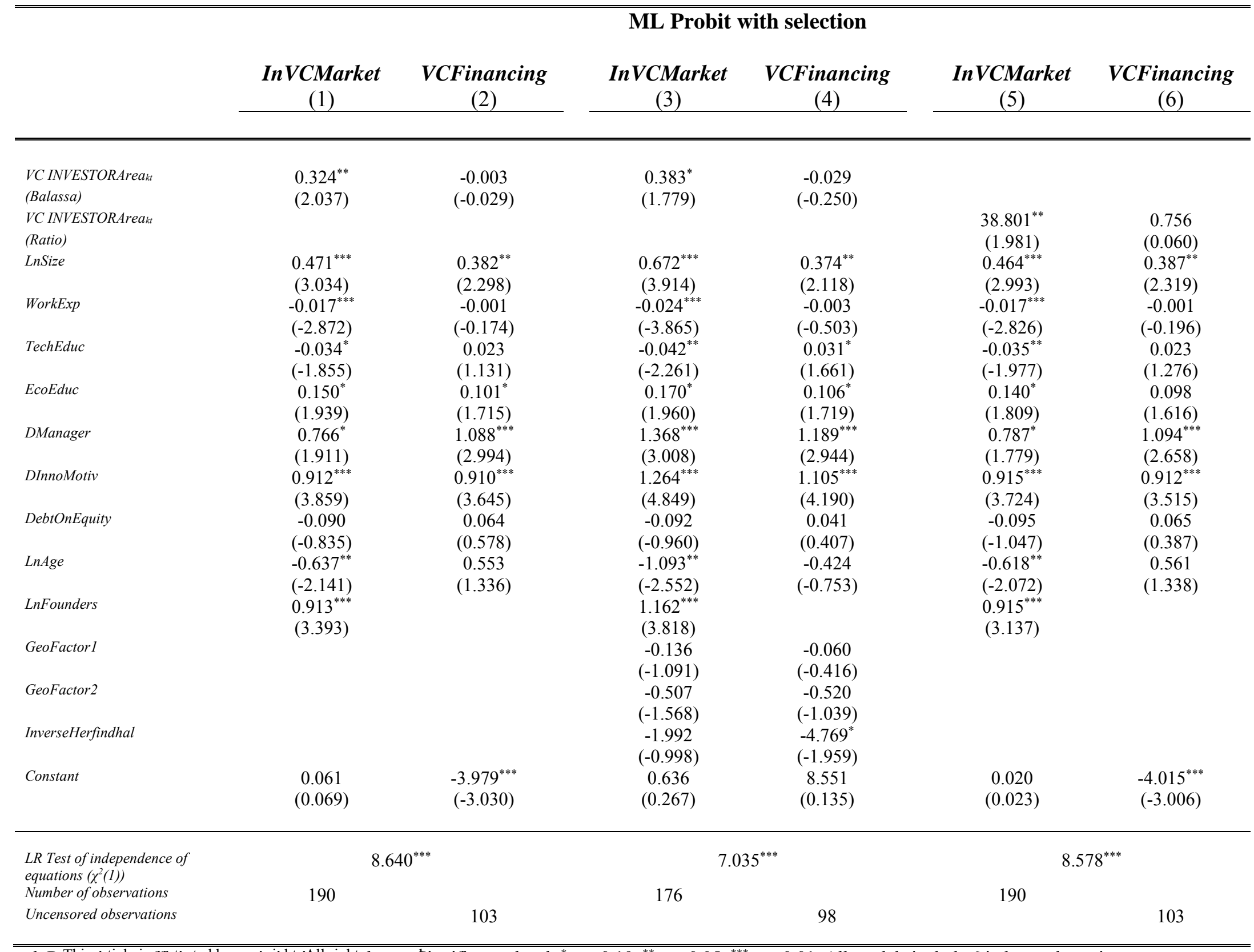

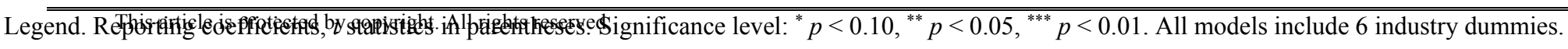


Table 5 - Statistics about the location choice of founders

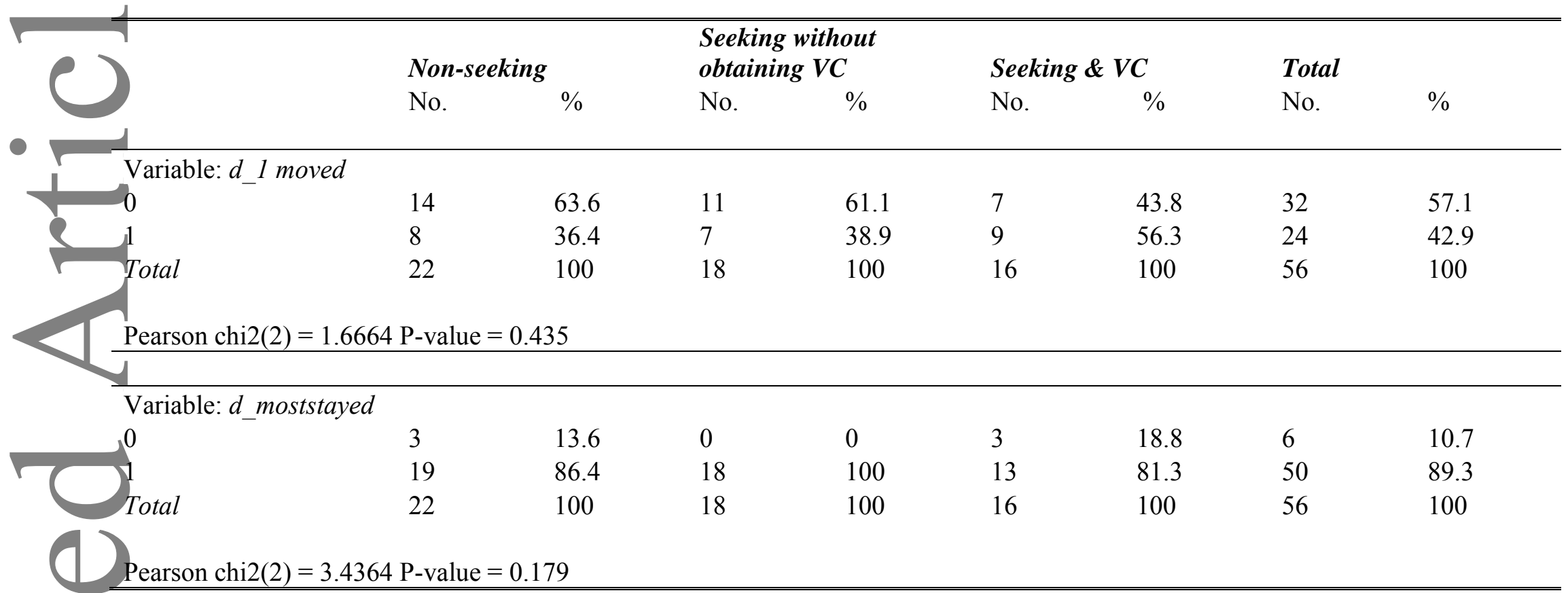

Legend. The two reported Pearson chi-square statistics test the null hypothesis of no differences in the frequency cases between the variable's values ( 0 and 1$)$ across the three different categories (Non-seeking, Seeking without obtaining VC, Seeking \& VC). 


\section{Appendix A}

The sample we use in this work was drawn from the 2004 release of the RITA (Research on Entrepreneurship in Advanced Technologies) directory. As stated in the main text, this sample is representative of a population of 1,974 entrepreneurial growth-oriented high-tech ventures operating in Italy at the beginning of 2004. The use of official statistics in this domain is not possible for several reasons. First, in Italy, most individuals who are defined as self-employed by official statistics (i.e., independent employees) are actually salaried workers with atypical employment contracts. Unfortunately, on the basis of official data, such individuals cannot be distinguished from ownermanagers of a new firm. This means that the official number of NTBFs is enormously inflated, especially in sectors such as software, where atypical employment contracts are very popular. In addition, official data do not distinguish firms that were established by one or more entrepreneurs (i.e., owner-managed firms) from firms that were created as subsidiaries of other firms. This again inflates the number of NTBFs. Lastly, there are no official statistics about M\&As: therefore, one cannot distinguish from independent NTBFs those firms that were acquired by another firm and lost independence while keeping their legal status.

In the absence of reliable official statistics, the RITA directory developed at Politecnico di Milano is, at present, the most complete source of information on Italian NTBFs. The directory was created in 2000, and it was updated in 2002 and 2004. Several sources were used for its construction. These included i) lists of the companies that were members of the national entrepreneurial associations of the focal industries, ii) lists of the members of the regional sections of the Italian entrepreneurial association (Confindustria), iii) lists of the members of the local Chambers of Commerce, iv) lists of companies that participated in the most important industry trades and expositions, v) lists of companies that purchased advertising services in popular off-line (e.g., Kompass) and on-line (e.g., Infoimprese.it) directories, vi) the population of young firms that were granted by the Italian communication authority (AGCOM) a license to provide telecommunication services (including 
Internet access services), vii) the population of NTBFs that were incubated in a science park or a business innovation center (BIC) affiliated with the respective national associations, viii) the population of NTBFs that obtained equity financing from $\mathrm{VC}$ investors that adhere to the Italian financial investor association (AIFI), and ix) the population of VC-backed NTBFs that were included in VentureXpert. Lastly, information provided by the national financial press, specialized magazines, and other sectoral studies was also used in the compilation of the directory. Altogether, the 2004 release of the RITA directory comprises 1,974 firms that complied with the criteria related to industry of operation, age and independence mentioned in the Section Sampling Process and Sample Composition. For each firm, the name of a contact person (i.e., one of the owner-managers) is also provided. While the RITA directory is obviously not exhaustive of any self-employment episode in high-tech sectors, it provides extensive and accurate coverage of the population of Italian entrepreneurial ventures in this domain, excluding lifestyle companies, non-growth-oriented firms and other scarcely entrepreneurial acts. In particular, it is quite unlikely that potential candidates for VC investment in Italy in 2004 were excluded from the RITA directory. 


\section{Appendix B}

Table B1 - Alternative operationalizations of VC INVESTORArea

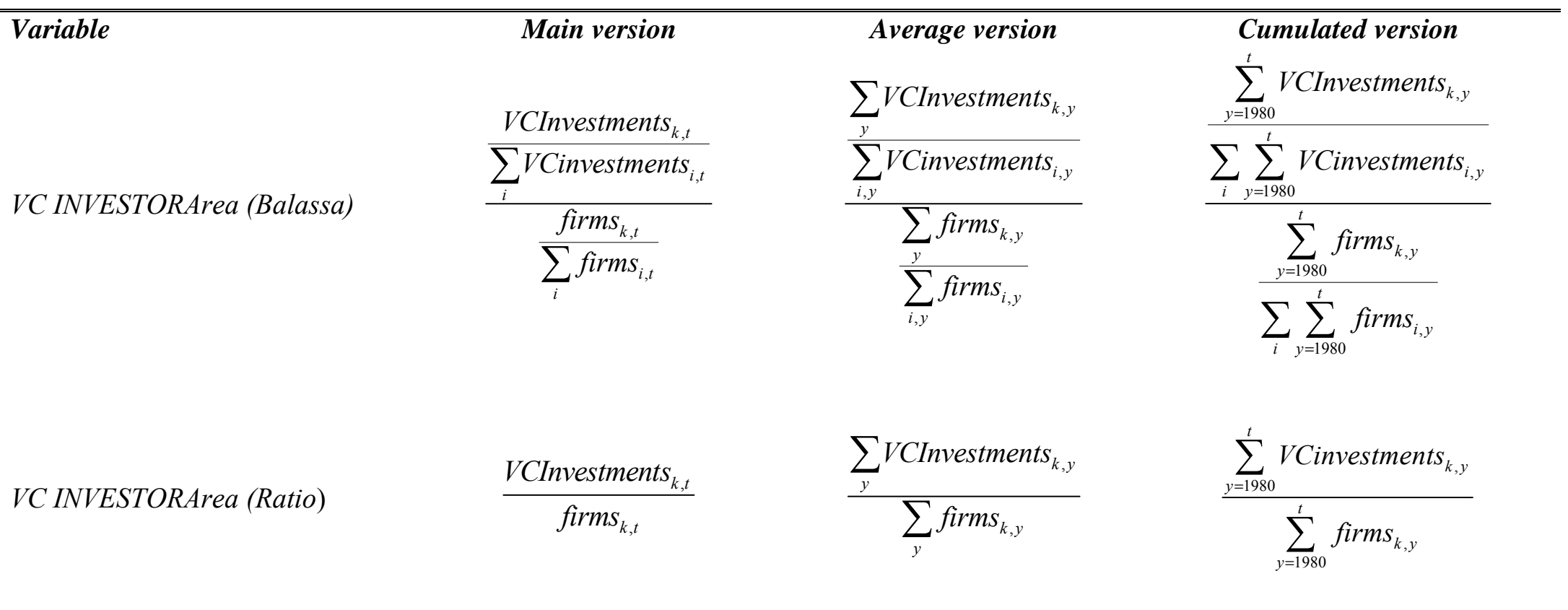

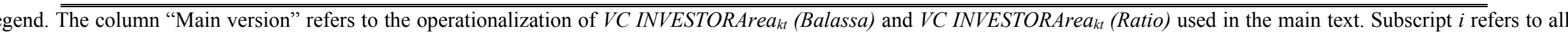
Italian regions (NUTS2 level), subscript $y$ to all years in the time-span 1980-2003, subscript $k$ indicates the region in which the focal NTBF is located, subscript $t$ indicates the year of oundation of the focal NTBF. The term firms indicates the number of active firms in high-tech sectors. Also note that the notation $y=1980$ refers to the first year in the time span. If therwise specified, the summations are over all the possible values that the index can take; e.g., $\sum_{i} V_{\text {Cinvestments }}$ i,t is the sum of the number of VC investments in year $t$ over regions in Italy, and $\sum_{y}$ firms $_{k, y}$ is the sum of the number of active high-tech firms over all possible years in the dataset. 